\title{
2018-2019 Öğretim Yılında Güncellenen Öğretmen Yetiştirme Lisans Programının İncelenmesi
}

\section{An analysis of the Teacher Training Undergraduate Program Updated in the 2018-2019 Educational Year}

\author{
Abdullah ÇETIN ${ }^{1}$, Serkan $\ddot{U N S A L} L^{2}$, Ebru HEKIMOĞLU
}

\begin{abstract}
${ }^{1}$ Sorumlu Yazar, Abdullah ÇETiN, Doç. Dr., Eğitim Bilimleri Bölümü, Eğitim Fakültesi, Kahramanmaraş Sütçü Imam Üniversitesi, Türkiye, abdcetin46@gmail.com, (https://orcid.org/0000-0003-1118-074)

${ }^{2}$ Doç. Dr., Ĕ̆itim Bilimleri Bölümü, Eğitim Fakültesi, Kahramanmaraş Sütçü İmam Üniversitesi, Türkiye, serkan-unsal09@hotmail.com, (https://orcid.org/0000-0003-0367-0723)

${ }_{3}^{3}$ Ögretmen, Milli Ĕgitim Bakanlığl, yukseklisans46@hotmail.com (https://orcid.org/0000-00024591-5728)
\end{abstract}

Geliş Tarihi: 29.03.2021

Kabul Tarihi: 17.10.2021

\section{ÖZ}

$\mathrm{Bu}$ araştırmanın amacı 2018 yılında yenilenen öğretmen yetiştirme lisans programlarının güncellenme nedenlerini, yapılan değişikliklerin olumlu/olumsuz yönlerini, değişikliklerin öğretmen yetiştirmeye katkılarının neler olabileceğini akademisyenlerin görüşleri dogrultusunda belirlemektir. Araştırma olgubilim deseninde yürütülmüş nitel bir çalışmadır. Araştırmanın çalışma grubunu bir üniversitenin eğitim fakültesinde görev yapan 10 gönüllü akademisyen oluşturmuştur. Araştırmada veriler yarı yapılandırılmış görüşme formu ile toplanmıştır. Elde edilen veriler, içerik analizi tekniği ile çözümlenmiştir. Araştırmanın sonucunda öğretmen yetiştirme lisans programının değişmesine neden olan faktörlerin önceki programdan kaynaklanan sorunlar, politik nedenler ve nitelikli öğretmen yetiştirme arayışı olduğu tespit edilmiştir. Akademisyenler güncellenen programda seçmeli derslerin sayısının arttırılması, mesleki derslerin ön plana çıarılması ve uygulamaya yönelik derslerin programda yer alması konusunda adımların atılmasını olumlu değişiklikler olarak değerlendirirken bazı derslerin programdan çıkarılması, ders içeriklerinin net olmaması ve her ne kadar uygulamaya yönelik dersler konusunda adım atılsa da programda sayılarının azlığı olumsuzluk olarak değerlendirmektedirler. Akademisyenlere göre güncellenen öğretmen yetiştirme programından kuramsal bilgiyi uygulamaya aktaracak çok yönlü öğretmenlerin yetiştirilmesine katkı sunması beklenmektedir. Bu araştırmadaki akademisyen görüşlerinin yükseköğretim kurumları tarafından öğretmen yetişme programları hazırlanırken dikkate alınması önerilmiştir.

Anahtar sözcükler: Öğretmen, öğretmen yetiştirme, lisans programları.

\begin{abstract}
The overall aim of this research is to reveal the reasons for the changes in the teacher training undergraduate programs updated in 2018, the perceptions of academicians' regarding the changes, their contributions to teacher training as well as the recommendations for improvement in line with academicians' views. Having a qualitative research design, the research utilized phenomenological design. The study group of the research consisted of 10 volunteer academicians working in the education faculty of a university. The research data were collected through a semi-structured interview form. Content analysis was used during data analysis. The research findings revealed that the reasons for the changes in the teacher training undergraduate programs resulted from the problems arising from the previous programs, political reasons and the quest for qualified teacher training. The academicians' positively evaluated some issues such as the
\end{abstract}


increase in the number of elective courses, the prominence of educational sciences, the steps to be taken in the implementation program, while they also made negative evaluations such as the removal of some of the courses, the vagueness of the course content and the lack of practical courses. The updated teacher training programmes are expected to contribute to the training of multi-faceted teachers who will transfer theory to practice. This research recommended that academicians' views be taken into consideration by the institutions of higher education while designing teacher training programs.

Keywords: Teacher, teacher training, undergraduate programs.

\section{GíRIŞ}

İnsanlığın başlangıcından günümüze bireyler yaşamlarını devam ettirebilmek, karşılaştıkları problemleri çözebilmek, toplumsal uyumu gerçekleştirebilmek ve daha konforlu bir hayat süredürebilmek için mevcut bilgi birikimlerini artırma arayışları içine girmişlerdir. $\mathrm{Bu}$ arayışın sonucu olarak başlangıçta basit formda gerçekleşen öğrenme ve öğretme süreci modern eğitim kurumları olan okulların açılmasıyla daha sistematik bir hâle dönüşerek "öğretmen" kavramını ortaya çıkarmıştır.

Türk Dil Kurumu (2021) tarafından "mesleği bilgi öğretmek olan kimse" olarak tanımlanan öğretmen, eğitim sisteminin en temel ögesi olarak kabul edilmektedir (Boudersa, 2016; Çapa ve Çil, 2000; Ingersoll ve Perda, 2008). Öğretmenlerin eğitim sisteminin en temel öğesi olarak kabul edilmesinin nedenleri; eğitimle ilgili her şeyin öğretmenlerin enerji ve becerileri çerçevesinde şekillenmesi (Center for Education National Research Council [CENRC], 2001), öğrencilerin entelektüel gelişimini sağlaması, yeni nesli gelecekte karșılaşacağı zorluklara hazırlaması (Hargreaves, 2009), öğrenciyi başarıya ulaștırması (Darling-Hammond, 2000; Hanushek, Kain ve Rivkin, 1998; Muñoz, Prather ve Stronge, 2011; Wright, Horn ve Sanders, 1997) ve hem toplumun hem de bireyin geleceğini şekillendirmesi (Berk, 2014) şeklinde açıklanabilir. Bu nedenlerle öğretmenlik mesleği ile ilgili konular üzerinde çok tartışılan ve eğitim bilimlerinde çok fazla araştırma yapılan konular arasında yer almaktadır.

Bir meslek olup olmadığı tarihsel süreçte sürekli tartışılmasına rağmen (Aslan, 2015) öğretmenlik, 21. yüzyılda geçirdiği dönüşüm ve değişim sonucunda profesyonel bir meslek olarak kabul edilmiştir (Yirci, 2016). Yapılan bir işin meslek olarak kabul edilmesi için gerekli olan ölçütler; spesifik, sistematik ve bilimsel bir bilgi yapısını içermesi, bilginin formal eğitim süreciyle edinilmesi; sosyal, ekonomik, bilimsel, teknolojik boyutlara sahip olması; bireye statü, prestij ve gelir kazandırması; bireysel ve toplumsal yaşam için zorunlu bir iş bölümü sonucu ortaya çıkması șeklindedir. Ayrıca bir işin meslek olarak kabul edilmesi, kişinin geçimini sağlamak için yaptığı sürekli ve örgütlü etkinliklerin bütününü içermesi gerekmektedir (Demir ve Acar, 1996; Gömleksiz, 2004; Guerriero, 2017; Köktaş, 2003; Ünal ve Ada, 1999). Bu ölçütlere göre öğretmenlik bir meslek olarak kabul edilebilir (Duran, 2001; Şişman, 2000). Yaman, Yaman ve Eskicumalı (2001) öğretmenlik mesleğini; 657 sayılı devlet memurluğu kanununa göre istihdam edilen, eğitim ve öğretim ile ilgili görevi yerine getiren meslek grubu olarak tanımlanırken Akyüz (2001), öğretmenliği bir kamu görevi olan öğretim ve eğitimi üstlenen bir meslek olarak tanımlamaktadır. Bu bağlamda öğretmenlik bir meslek olarak kabul edildiğine göre, mesleğin gereklerini yerine getirecek bireylerin yetiştirilmesi gündeme gelmekte ve "öğretmen yetiştirme" kavramı ön plana çıkmaktadır.

Öğretmen yetiştirme; öğretmenlerin istihdamı, yetiştirilmesi ve bunlara bağlı olarak oluşan birtakım politikaları içeren bir yapıdır (Karslı ve Güven, 2011). Türkiye'de öğretmen yetiştirmenin tarihsel gelişimine bakıldığında bu konunun yaklaşık 160 yıllık bir geçmişe sahip olduğu anlaşılmaktadır (Aydın, 1998; Kilimci, 2011). Öğretmen yetiştirme, Osmanlı İmparatorluğu'nun son döneminde ve Cumhuriyet Dönemi'nin ilk y1llarında üzerinde durulan önemli konular arasında yer almaktadır. Özellikle Cumhuriyet Dönemi’nin ilk yıllarında halkın 
büyük bir çoğunluğunun temel okuma-yazma becerisine sahip olmaması (Akyüz, 2001), öncelikli olarak ilkokullara yönelik öğretmen yetiştirme sorununu gündeme getirmiştir. İlkokullara öğretmen yetiştirmeye yönelik değişik uygulamalar farklı zamanlarda farklı şekillerde gerçekleştirilmiştir. Bu farklılıklardan en dikkat çekici olanı ise 1924-1954 yılları arasında şehir/kasaba ve köylere yönelik iki farklı öğretmen yetiştirme programının uygulanmasıdır (Sağlam, 2011). Köy ilkokullarında görev yapacak öğretmenler yetiştirmek için; köy muallim mektebi, köy öğretmen okulları, eğitmen kursları ve köy enstitüleri açılırken şehir/kasaba ilkokullarında görev yapacak öğretmenler için ilköğretmen okulları açılmıştır (Tangülü, Karadeniz ve Ateş, 2010). 1954'te köy enstitülerinin kapanmasıyla birlikte köye ayrı şehre ayrı öğretmen yetiştirme sisteminden vazgeçilmiş tüm ilkokullarda görev yapabilecek öğretmen yetiştiren kurumlar ilkögrretmen okulu adı altında birleştirilmiştir. 1973 tarih ve 1739 sayılı Milli Eğitim Temel Kanunuyla "Öğretmenlik, devletin eğitim-öğretim ve bunlarla ilgili görevlerini üzerine alan özel ihtisas mesleğidir." hükmü getirilmiş ve öğretmenlerin hangi öğretim kademesinde görev alacak olursa olsun, yükseköğrenim kurumlarında öğrenim görmelerinin gerekliliği öngörülmüştür (MEB, 2017). Bu doğrultuda 1974-1975 eğitim-öğretim yılından itibaren ilkokullarda görev alacak sınıf öğretmenlerini yetiştirmek üzere iki yıllık eğitim enstitülerinin açılması kararlaştırılmışıır. 1974-1975 eğitim-öğretim döneminde kademeli olarak bazı ilköğretmen okulları iki yıllık eğitim enstitülerine dönüştürülürken, bazıları ise öğretmen liselerine dönüştürülmüştür (Tangülü vd., 2010).

Öğretmen yetiştiren tüm kurumlar, 1982 yılında Yüksek Öğretim Kuruluna (YÖK) bağlanmıştır. 1981'de sayıları 17'ye indirilen iki yıllık eğitim enstitüleri ve eğitim yüksek okulları ile 3 yıllık eğitim enstitülerinin eğitim-öğretim süresi 4 yıla çıkartılarak bu kurumlar, eğitim fakültesi adı altında birleştirilmiştir (Abazaoğlu, Yıldırım, Yıldızhan, 2016; Ergün, 1987). $\mathrm{Bu}$ tarihten itibaren eğitim fakültelerinde çeşitli düzenlemelere gidilmiştir. İlk düzenleme 19881989 eğitim öğretim yılında sınıf öğretmeni yetiştiren eğitim yüksekokullarının eğitim sürelerinin 4 yıla çıkarılmasıdır. 1992 yılında bu yüksekokulların bazıları eğitim fakültelerine dönüştürülmüş bazıları ise sınıf öğretmenliği bölümü olarak mevcut eğitim fakültelerine bağlanmıştır (Özoğlu, 2010). YÖK tarafından gerçekleştirilen/yürütülen bir planlama ile eğitim fakültelerinde standart bir model oluşturulmaya çalışılmıştır (Akdemir, 2013).

Öğretmen yetiştirme programlarıyla öğretmen yetiştirmede bir standart oluşturulmaya çalışan YÖK, 1997 yılında öğretmen yetiştirme konusunda kapsamlı bir düzenlemeye gitmiştir. $\mathrm{Bu}$ düzenleme ile öğretmen yetiştiren kurumların programları, eğitim süreleri, öğretmen yetiştirme modelleri, programların içeriği, MEB ile işbirliği kapsamında yapılacak faliyetler, eğitim-istihdam uyumu gibi bir çok konuda değişiklik ve yenilikleri hayata geçirilmiştir (YÖK, 2007). Öğretmen yetiştirme programı konusunda 1997 yılında yapılan yeniden yapılandırmanın aksayan yönlerinin giderilmesi amacıyla 2006-2007 yılında yeniden düzenlemeye gidilmiştir. $\mathrm{Bu}$ doğrultuda meslek bilgisi derslerinde ve bu derslerin işleyişinde birtakım düzenlemeler yapılmıştır. Bu düzenlemelerle 1997 yılında sayısı azaltılan genel kültür derslerinin oranları arttırılmış, çakılı ders uygulamasından vazgeçilerek eğitim fakültelerine programın \% $\% 25$ 'ini belirleme yetkisi getirilmiş ve seçmeli ders sayısının arttırılması yetkisi tanınmış, uygulamalı ders saatleri azaltılmış, meslek bilgisi dersleri yıllara dağıtılarak beş yıllık birleştirilmiş eğitime geçilmiştir. Böylelikle 1997 yılındaki yeniden yapılanmada gerçekleştirilen düzenlemelerin birçoğundan vazgeçilmiştir (Özoğlu, 2010).

Çağımızda toplumun ihtiyaç ve taleplerindeki değişmeler, eğitim bilimlerinde ve öğretmen yetiştirme alanında yaşanan gelişmeler ile Türk eğitim sistemindeki yapısal değişiklikler, öğretmen yetiştirme programlarının güncellemesini zorunlu hâle getirmiştir (YÖK, 2018). Bu bağlamda 2018 yılında YÖK tarafından öğretmen yetiştirme programlarında değişikliğe gidilmiştir. Dünyadaki gelişmeler doğrultusunda öğretmen yetiştirme programları, alan bilgisinin yanı sıra, alan eğitimine ve öğretimine yönelik mesleki bilgi ve beceriler kazandırmayı önceleyecek şekilde oluşturulmuştur (YÖK, 2018). 1997, 2006 ve 2009 yıllarında gerçekleştirilen program değişikliklerinin odağında ilköğretime öğretmen yetiştiren öğretim 
programları yer alırken 2018 yılında gerçekleştirilen değişikliklerin odağına öğretmen yetiştiren tüm lisans programları yer almaktadır (Yurdakal, 2018). YÖK'ün Bologna sürecine dönük uyum çalışmaları kapsamında 2018 yılında yaptığı değişiklikle, lisans programlarında ortak seçmeli ders havuzları oluşturulmuştur (YÖK, 2018). Öğretmen adaylarının alanıyla ilgili mesleki bilgi ve becerilerinin yanında entelektüel, sosyal ve kültürel yönlerden de donanımlı yetişebilmeleri için "Türk Eğitim Tarihi”, "Eğitim Sosyolojisi" ve "Eğitim Felsefesi" dersleri eğitim fakültelerinde açık bulunan tüm lisans programlarında zorunlu mesleki bilgi dersleri olarak tanımlanmıştır. Ayrıca, bu programlara "Eğitimde Ahlâk ve Etik" dersi konulması ile öğretmen adaylarının meslek ahlâkı ve etiğiyle ilgili konularda da bilgi ve beceri kazanması öngörülmüştür (YÖK, 2018). Diğer taraftan öğretmenlerin öğretim teknolojilerini etkin bir şekilde kullanabilmesi ve ders-öğretmen-teknoloji birlikteliğinin oluşturulabilmesi amaciyla, tüm programlarda "Öğretim Teknolojileri” dersine zorunlu mesleki bilgi dersi kapsamında yer verilmiştir.

Türkiye'de öğretmen yetiştirmeyle ilgili fakültelerin programlarında ulusal ve uluslararası gelişmelere göre birçok değişiklik yapılmış ve yapılmaya da devam edilmektedir (MEB, 2017). Yapılan bu değişikliklerin nihai amacı, dünyada öğretmen eğitiminde ve yeterliklerinde yönelimin "nitelik" odaklı olması (Erdem, 2015) ve Türkiye'nin de bu yönelime uyum sağlama çabasıdır. Bu amacın gerçekleşmesi, güncellenenen öğretmen yetiştirme lisans programlarının uygulayıcıları olan akademisyenlerin; söz konusu programları benimseme, bu programları uygulama konusunda istekli olma ve programların başarılı olacağına inanmalarına bağlıdır (Guskey, 2002; Ünsal, Çetin, Korkmaz ve Aydemir, 2018; Çetin, 2017). Programın uygulayıcıları olan kişilerin görüşlerinin göz ardı edilmesi, yapılan değişikliğin başarısız olmasının yanında, para, zaman ve enerji kaybına da neden olmaktadır (Ornstein ve Hunkins, 2014). Bu araştırmadan; programdaki eksikliklerin, uygulamada yaşanan aksaklıkların uygulayıcıların program hakkındaki algılarının tespit edilemesine katkı sunacağı beklendiğinden araştırma önem arz etmektedir. Ayrıca akademisyenlerin görüşlerinden elde edilecek verilerin 2020 yılında gerçekleşen değişiklikle ders kategorileri (Alan Eğitimi Dersleri, Öğretmenlik Meslek Bilgisi Dersleri ve Genel Kültür Dersleri) ders sayıs1, ders saati/kredi sayıs1 ve yoğunluğu aynı kalmak şartıyla yükseköğretime kurumlarına bırakılan "öğretmenlik programlarındaki derslerin, müfredatların ve kredilerin belirlenmesine rehberlik etmesi beklenmektedir. Alanyazın incelendiğinde 2018 yılında uygulamaya konulan lisans programları ile daha önceki yıllarda uygulanan lisans programlarını bazı bölümler kapsamında karşılaştırıldığg (Akarsu, Yılmazer ve Geçit, 2020; Sağdıç, 2018), 2018 lisans programlarının bazı bölümleri akademisyen görüşleri bağlamında incelendiği (Ağçam ve Babanoğlu, 2020; Aykaç ve Stebler, 2019; Dağtekin ve Zorluoğlu, 2019; Demir, Akbaş ve Gök, 2021) görülmüştür. Ancak 2018 öğretmen yetiştirme lisans programlarının bütünsel bir bakış açısı ile ele alınmadığı görülmüştür. Bu durum araştırmacılar tarafından eksiklik olarak düşünülmüş ve bu eksiliğin giderilmesi adına araştırmanın problem cümlesi, "2018 yılında yenilen öğretmen yetiştirme programında yapılan değişiklikler hakkında akademisyenlerin görüşleri nelerdir?" şeklinde oluşturulmuştur. Bu kapsamda araştırmanın amacı; 2018 yılında yenilenen öğretmen yetiştirme lisans programlarının güncellenme nedenleri, yapılan değişikliklerin olumlu/olumsuz yönleri ile değişikliklerin öğretmen yetiştirmeye katkılarının neler olabileceğini akademisyenlerin görüşleri dogrultusunda belirlemektir. Bu amaç doğrultusunda aşağıdaki sorulara cevap aranmıştır.

S.1. Akademisyelere göre öğretmen yetiştirme programının güncellenmesinin sebebi nelerdir?

S.2. Akademisyelere göre güncelenen öğretmen yetiştirme programının olumlu ve olumsuz yönleri nelerdir?

S.3. Akademisyelere göre nitelikli öğretmen yetiştirilmesine güncellenen öğretmen yetiştirme programının katkısı neler olabilir? 
S.4. Akademisyenlerin güncellenen öğretmen yetiştirme programlarının geliştirilmesine yönelik önerileri nelerdir?

\section{YÖNTEM}

\subsection{Araştırmanın Modeli}

$\mathrm{Bu}$ araştırma, nitel araştırma desenlerinden olgubilim deseninde yürütülmüştür. Olgubilim deseninde yürütülen araştırmalar, olgu ile ilgili katılımcıların bakış açısını, deneyimlerini ve algılarını ortaya çıkarmak amacıyla gerçekleştirilmektedir (Johnson ve Christensen, 2012). Olgubilim deseni araştırmaları farkında olduğumuz ancak derinlemesine bilgi sahibi olunmayan olayları ve olguları derinlemesine incelemeyi amaçlayan araştırmalardır. Olgular; olaylar, algılar, tutumlar, deneyimler, yönelimler ve durumlar şeklinde karşımıza çeşitli formda çıkabilmektedir (Yıldırım ve Şimşek, 2011: 72). Bu araştırmada ele alınan olgu, 2018 yılında güncellenen ögretmen yetiştirme lisans programıdır.

\subsection{Araştırma Grubu}

Olgubilim araştırmalarında katılımcıların olguyu yaşayan, olguyu dışa vurabilecek, olguyla ilişkili birincil kişiler olmasına dikkat edilmelidir (Creswell, 2016; Patton, 2014; Yıldırım ve Şimşek, 2011). Bu araştırmanın amacına uygun olarak araştırmanın çalışma grubunu Anadolu'da bir üniversitenin Eğitim Fakültesinde görev yapan 10 gönüllü akademisyen oluşturmuştur. Araştırmaya katılan akademisyenler öğretmen yetiştirme lisans programlarında derse giren, bir önceki programı uygulayan, olguyla ilgili deneyime sahip ve güncellenen öğretmen yetiştirme programından birinci dereceden etkilenen/etkilenecek olan kişilerdir. Katılımcılar güncellenen öğretmen yetiştirme lisans programında yapılan değişiklikleri değerlendirebilecek ve bakış açısı sunabilecek deneyime sahiptirler. Katılımc1 akademisyenler etik kurallarına uymak adına A1...A10 şeklinde kodlanmıştır. Katılımcıların demografik özellikleri Tablo 1'de sunulmuştur.

Tablo 1. Araştırmaya Katılan Akademisyenlerin Demografik Özellikleri

\begin{tabular}{lllll}
\hline Kod & Cinsiyet & Ana Bilim Dalı & Akademik Unvan & Hizmet Süresi \\
\hline A1 & Kadın & Eğitim Programları ve Öğretimi & Doç. Dr. & $16-20$ Yıll \\
A2 & Erkek & Sosyal Bilgiler Eğitimi & Doç. Dr. & $6-10$ Y1l \\
A3 & Kadın & İngiliz Dili Eğitimi & Dr. Öğr. Üyesi & $6-10$ Y1l \\
A4 & Erkek & Fen Bilgisi Eğitimi & Doç. Dr. & $6-10$ Y1l \\
A5 & Erkek & Eğitim Yönetimi & Dr. Öğr. Üyesi & $6-10$ Y1l \\
A6 & Erkek & Eğitim Programları ve Öğretimi & Doç. Dr. & $1-5$ Y1l \\
A7 & Kadın & İlköğretim Matematik & Dr. Öğr. Üyesi & $1-5$ Y1l \\
A8 & Erkek & Eğitim Yönetimi & Dr. Öğr. Üyesi & $1-5$ Y1l \\
A9 & Erkek & Eğitim Yönetimi & Doç. Dr. & $16-20$ Y1l \\
A10 & Erkek & Eğitim Programları ve Öğretimi & Doç. Dr. & $16-20$ Yil \\
\hline
\end{tabular}

Tablo 1 incelendiğinde çalışma grubundaki erkek (\%70) akademisyenlerin sayısı kadın akademisyenlerin sayısından fazladır. Çalışma grubundaki akademisyenlerin çoğu; Eğitim Programları ve Öğretimi (\%30) ve Eğitim Yönetimi (\%30) Ana Bilim Dalında görevli, Doç. Dr. ünvanlı $(\% 70)$ ve $6-10$ yıl (\%40) arası kıdemli öğretim üyeleridir.

\subsection{Veri Toplama Araçları ve Verilerin Toplanması}

Görüşme, sistematik veri toplamak için özellikle sosyal bilimlerde yaygın kullanılan araçlarından biridir. Görüşme bireylerin çeşitli konulardaki bilgilerini, düşüncelerini, tutumlarını ve deneyimlerini ortaya çıarmak için kullanılan en kestirme yoldur (Creswell, 2016; Merriam, 2013; Patton, 2014). Görüşme, bireylerin gözlemleyemediğimiz davranışlarının sebebini öğrenmek (Merriam, 2013), kişilerin tecrübelerini ortaya çıkarmak, olayların bireyleri nasıl etkilediklerini tespit etmek (Patton, 2014) için gerçekleştirilebilir. Bu araştırmada katılımcıların 
görüşlerini almak için yarı yapılandırılmış görüşme formu kullanılmıştır. Yarı yapılandırmış görüşme formu, katılımcıların demografik özelliklerini ve 2018-2019 öğretmen yetiştirme programı hakkındaki görüşlerini belirlemek için sekiz sorudan oluşturulmuştur. Görüşme formu hazırlanırken alanyazın taraması yapılmış ve Kahramanmaraş Sütçü İmam Üniversitesi Eğitim Fakültesinde görev yapan iki öğretim üyesinden görüş alınmıştır. Görüşme öncesinde katılımcılara araştırma hakkında kısa bir sunum yapılarak katılım için gönüllü olup olmadıkları sorulmuştur. Görüşmeler katılımcıların görev yaptıkları kurumdaki odalarında gerçekleştirilmiştir. Bazı görüşmeler katılımcılarla karşılıklı soru-cevap şeklinde gerçekleştirilmiş ve katılımcıların yanıtları araştırmacı tarafından görüşme formlarına yazılarak kaydedilmiştir. Bazı görüşmeler katılımcıların izni ile ses kaydına alınmıştır. Bazı görüşmelerde ise katılımcının kendisi görüşme formunu doldurmuştur. Görüşmeler yaklaşık olarak $30 \mathrm{dk}$ sürmüştür. İlk görüşme yapıldıktan yaklaşık 4 ay sonra katılımcılara ikinci görüşme için gidildiğinde gidilen ilk üç katılımcı görüşlerinin değişmediğini belirtmesi üzerine katılımcılarla ikinci görüşmeler yapılmamıştır.

\subsection{Verilerin Analizi}

$\mathrm{Bu}$ araştırmada elde edilen verilerin analizinde içerik analizi kullanılmıştır. İçerik analizi elde edilen verilerin derinlemesine incelenmesi sonucu kodlarm belirlenmesini daha sonra bu kodlar doğrultusunda temaların oluşturulmasını içerir (Berg ve Lune, 2015; Creswell, 2016; Meriam, 2013; Patton, 2014). İçerik analizinde toplanan verileri açıklayacak kavramlar bütünsel bakış açısıyla bir araya getirilerek aralarındaki ilişki ortaya çıkarılır ve okuyucunun anlayacağı sistematik bir şekilde yorumlanır (Berg, 2001; Yıldırım ve Şimşek, 2011). Bu araştırmada öncelikle elde edilen tüm veriler düzenlenerek araştırmacılar tarafından okunmuş kodlamaya hazır hâle getirilmiştir. Daha sonra katılımcılar tarafından verilen cevaplar iki araştırmacı tarafından ayrı ayrı incelenerek öncelikle kodlar oluşturulmuş, daha sonra ilişkili kodlar bir araya getirilerek temalar oluşturulmuştur. $\mathrm{Bu}$ araştırmada içerik analizinin doğasına uygun olarak veriden gelen bulguya odaklanıldığından tümevarımsal analiz yöntemi benimsenmiştir. Patton (2014) içerik analizinde tümavarımsal analiz yönteminin uygun olacağını belirtmişsir.

Merriam (2013) nitel araştırmalarda geçerlik ve güvenirliğin sağlanması için öncelikle araştırmanın etik bir biçimde sürdürülmesi gerektiğini belirmiştir. Bu araştırmada geçerlik ve güvenirliğin sağlanması için etik kurallara uyulmuştur. Nitel araştırmada geçerlik ve güvenirlik adına inandırıcılık, aktarılabilirlik, tutarlılık ve teyit edilebilirlikle ilgili çalışmaların yapılması gerektiği vurgulanmaktadır (Lincoln ve Guba, 1985). Bu araştırmada inandırıcılığ 1 artırmaya yönelik araştırmanın tüm aşaması ve katılımcılar hakkında ayrıntılı bilgi verilmiş, uzman görüşüne başvurulmuş ve katılımcı teyidi alınmıştır. Creswel (2016) ayrıntılı bilgi vermenin, okuyucunun, araştırmanın inandırıcılığı hakkında karar vermesini sağladığını belirtmiştir. Merriam (2013), araştırmanın inandırıcılığını artırmak için araştırmanın bir uzmana sunulması ve katılımcı teyidinin alınması gerektiğini vurgulamıştır. Nitel araştırmalarda araştırma sonuçları genellenebilir olmadığından (Merriam 2013; Patton, 2014; Yıldırım ve Şimşek, 2011) genellenebilirlik yerine "aktarılabilirlik" kavramı kullanılmış ve bu kavram "bir çalışmanın bulgularının diğer durumlara hangi derece veya kapsamda uygulanabileceğini o durumdaki kişilere bırakma işi” olarak açıklanmıştır (Merriam 2013; Seggie ve Bayburt, 2015). Bu araştırmada aktarabilirliği sağlama adına ayrıntılı açıklama yapılımış ve doğrudan alıntılara yer verilmiştir. Ayrıca okuyucular için anlaşılır bir dil kullanılmış ve araştırma bulguları şekillerle desteklenmiştir. İnsan hayatı sürekli değişmesi nedeniyle, insan odaklı nitel araştırmaları aynı şartlarda tekrarlamak pek mümkün olmamaktadır. Bu yüzden nitel araştırmalarda güvenirlik kavramı yerine tutarlılık kavramı kullanılmaktadır. Tutarlıklıkta araştırma verileriyle araştırma sonuçlarının birbiriyle tutarlı olması gerekir (Merriam, 2013; Yıldırım ve Şimşek, 2011). Bunun yanında, Creswell (2016) göre, nitel araştırmalarda güvenirliği sağlamak için veri setlerinin birden fazla araştırmacı tarafından kodlanarak kodlar arasındaki uyuma bakılması gerekmektedir. $\mathrm{Bu}$ araştırmada veri seti iki araştırmacı tarafından ayrı ayrı kodlayarak kodlamalar arası uyum tespit edilmiştir. Kodlayıcılar arası uyum, Miles ve Huberman'ın (1994, s.64) formülü 
(Güvenirlik $=$ Görüş birliği/Görüş birliği + Görüş ayr1lığ $X$ 100) kullanılarak hesaplanmış kodlayıcılar arasındaki uyum oranı .88 olarak bulunmuştur. Akay ve Ültanır (2010: 80) kodlayıcılar arası uyum değerinin .70'ten yüksek olduğu durumlarda kodlamalarının güvenilir olduğunu belirtmektedir. Ayrıca, farklı kodlamaların olduğu durumlarda araştırmacıların uzlaşması gerektiği belirtildiğinden (Silverman, 2005), söz konusu durumlarda araştırmacılar tartışarak kodlamalar üzerinde fikir birliğine varmıştır. Ayrıca kodlar bir katılımcının teyidine sunularak onay alınmıştır. Bu araştırmada teyit edilebilirlik adına, araştırmanın verileri ve raporları bilgisayar ortamında dosyalanarak istenildiği anda denetlenebilir hâle getirilmiştir. Creswell (2016) araştırma verilerinin ilgililerin teyidi için dış denetime açık olması gerektiğini belirtmektedir.

\section{BULGULAR}

Araştırmanın bu bölümünde akademisyen görüşlerinden elde edilen, 2018 yılında yenilen öğretmen yetiştirme programının değişme nedenleri, değişikliklerin olumlu ve olumsuz yönleri, değişikliklerin öğretmen yetiştirmeye katkılarının neler olabileceği ve ileride geliştirilecek programa yönelik akademisyen önerileri ile ilgili bulgular yer almaktadır. Verilerden elde edilen bulgular tema ve kodlar şeklinde sunulmuştur. Bulgular alt amaçlar doğrultusunda şekil oluşturularak verilmiştir.

\section{1 Öğretmen Yetiştirme Programının Değişme Nedenleri Hakkındaki Akademisyen Görüşlerine İlişkin Bulgular}

Araştırmanın cevap aradığı birinci sorunun amacı, öğretmen yetiştirme programının değişme nedenlerini akademisyen görüşleri doğrultusunda tespit etmektir. Bu amaçla elde edilen bulgular Şekil 1'de verilmiştir.

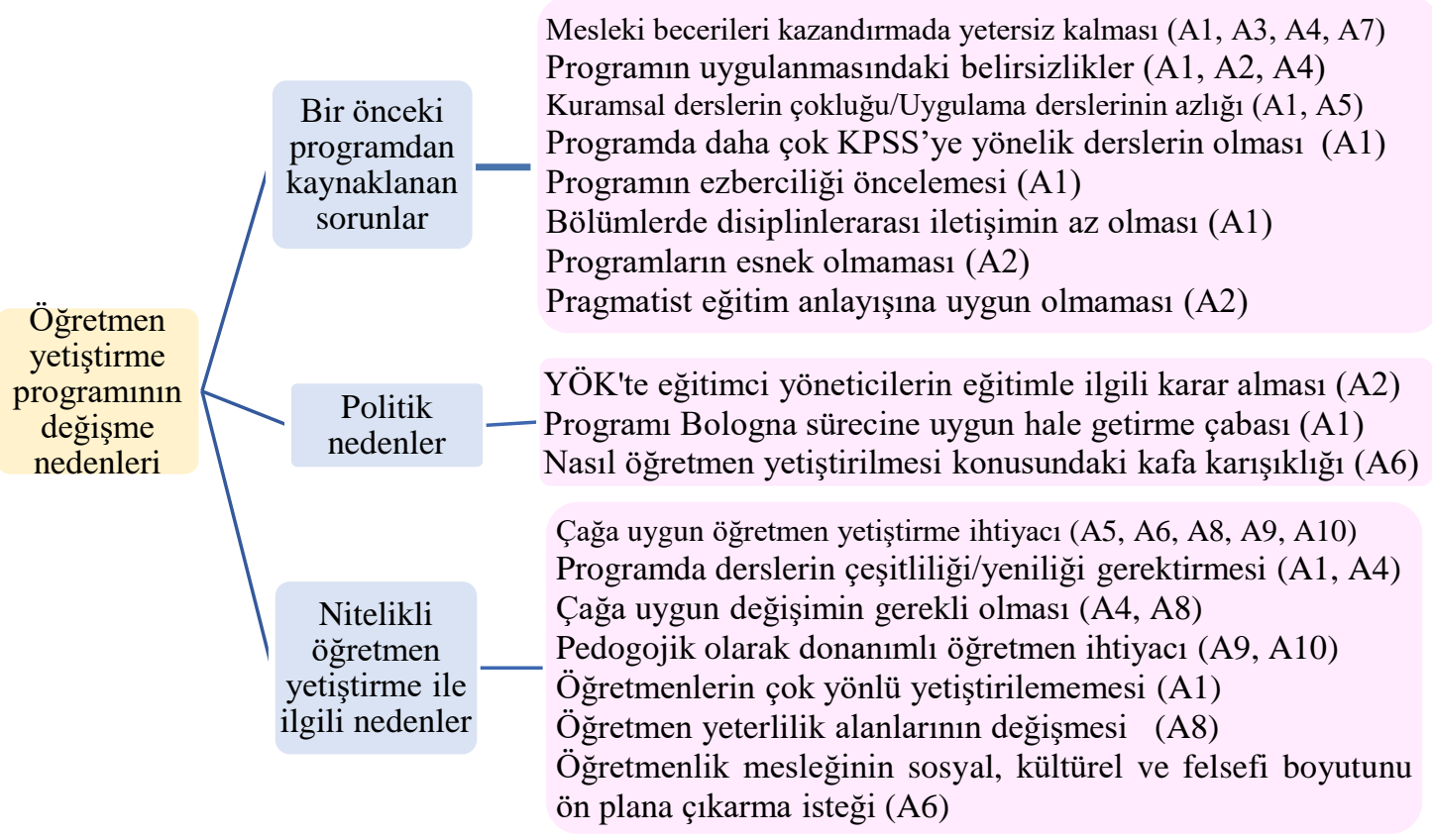

Şekil 1. Öğretmen Yetiştirme Programının Değişme Nedenleri

Şekil 1 incelendiğinde akademisyenlerin öğretmen yetiştirme programının değişme nedenlerine yönelik görüşleri bir önceki programdan kaynaklanan sorunlar, politik nedenler ve nitelikli öğretmen yetiştirme çabası temaları altında toplanmıştır. Bir önceki programdan 
kaynaklanan bazı sorunlar; mesleki becerileri kazandırmada yetersiz kalması (A1, A3, A4, A7), programın uygulanmasındaki belirsizlikler (A1, A2, A4) ve kuramsal derslerin çokluğudur (A1, A5). Bir önceki programın mesleki becerileri kazandırmada yetersiz kaldığını A7 "Eski programda yer alan lisans derslerinin ögrencilerin alanlarına yönelik mesleki beceri kazanmalarını tam olarak sağlayamaması." şeklindeki cümlesi ile vurgulamıştır. Önceki programı uygulamada belirsizliğin olduğunu A2 "Belirsizlik vardl, kim hangi derse girecek belli değil, belirsizliği ortadan kaldırmak için değiş̧tirilmiştir.” şeklindeki cümlesi ile ifade etmiştir. Teorik derslerin azaltıldığını A1 "Programlardaki alan kodlu derslerde teorik içerik azalıtımış." cümlesi ile ifade etmiştir. A1 bir önceki programın KPSS yönelik ezbere dayalı dersleri içerdiğini ve bölümler arası iletişimin az olduğunu vurgulamıştır. Konu ile ilgili A1'in görüşü "Öğretmenlerin çok yönlü yetiştirilememesi, ezberci bir eğitimin olması ders dağılımlarının çeşitliliği gerektirmesi başka fakülte ve bölümlerle disiplinlerarası iletişimin az olması, daha çok KPSS sınavına yönelik derslerin olması." şeklindedir. A2 ise bir önceki programın esnek olmadığını ve pragmatist felsefe yaklaşımına uymadığını belirmiștir. Bu konuyu A2 "Eski program fazla esnek değildi. Neticede seçmeli dersler çoğaltılarak hem özerkleşti hem de esnetildi. Pragmatist eğitim anlayışına uygun bir müfredat oluşturulmaya çalışılmıştır." şeklindeki cümlesi ile ifade etmiştir.

Şekil 1'de görüldüğü gibi programın değişme nedenlerinden biri de politik nedenlerdir. YÖK yönetim kurulunda eğitimci yöneticinin yer alması, programın Bologna sürecine uygun hâle getirilmeye çalışılması, nasıl öğretme yetiştirileceği konusunda kafa karışıklığı programın değişmesine neden olan politik faktörlerdir. YÖK'te eğitimci bir yöneticinin programın değişmesine önderlik ettiğini A2 "YÖK'te eğitimci olarak .... etkisi büyüktür." șeklindeki cümlesi ile belirtirken, Bologna sürecinin etkili olduğunu A1 "Yeni program Bologna süreci ile daha uyumlu hale getirilmek istenmiştir." cümlesi ile belirtmiştir.

Nitelikli öğretmen yetiştirme ile ilgili nedenler; çağa uygun öğretmen yetiştirme ihtiyacının ortaya çıkması (A5, A6, A8, A9, A10), ders dağılımının yeniliği ve çeşitliliği gerektirmesi (A1, A4), değişimin gerekli olması (A4, A8), pedagojik olarak donanımlı öğretmenlere ihtiyacın olması (A9, A10) ile öğretmenlerin yeterlik alanlarının değişmesidir (A8). Örneğin konu ile ilgili A5'in görüşü "Hizmet öncesi yetiştirme süreçlerinin kalitesini artırarak daha nitelikli ögretmen yetiştirmek amacıyla değiştirildiğini düşünüyorum." şeklinde iken A8'in görüşü "Çağdaş öğretmen niteliklerinde oluşan değişimler, ögretmenlerin yeterlilik alanlarının farklılaşması, ögretim programlarındaki değişiklikler, öğretmen yetiştirmenin çă̆ın gerektirdiği şekle büründürmek." şeklindedir. Diğer nedenler ise, bir önceki programla çok yönlü öğretmenin yetiştirilememesi (A8) ve öğretmenlik mesleğinin sosyal, kültürel ve felsefi boyutunun ön plana çıkarılmak istenmesidir (A6). Konu ile ilgili Ö6 görüşünü "Programın değişme gerekçesi ögretmenlik mesleğinin sosyal, kültürel ve felsefi boyutunun ön plana çıkartılması arayışının bir uzantısıdır." şeklindeki cümlesi ile belirtmiştir.

\subsection{Güncelenen Öğretmen Yetiştirme Programının Olumlu ve Olumsuz Yönleri Hakkındaki Akademisyen Görüşlerine İlişkin Bulgular}

Eğitim fakültelerinde görev yapan akademisyenlerin güncellenen öğretmen yetiştirme programında yapılan değişiklikleri olumlu mu yoksa olumsuz mu gördüklerine yönelik görüşlerinin belirlenmesi araştırmada cevap aranan ikinci sorudur. Çalışmaya katılan akademisyenlerin görüşlerinden elde edilen bulgular Şekil 2'de verilmiştir. Bazı akademisyenler yapılan değişiklikleri yerinde/doğru bulurken (A4, A5), bazı akademisyenler ise yapılan değişikliklerin bir kısmını olumlu bulmaktadırlar (A2, A8, A10). 


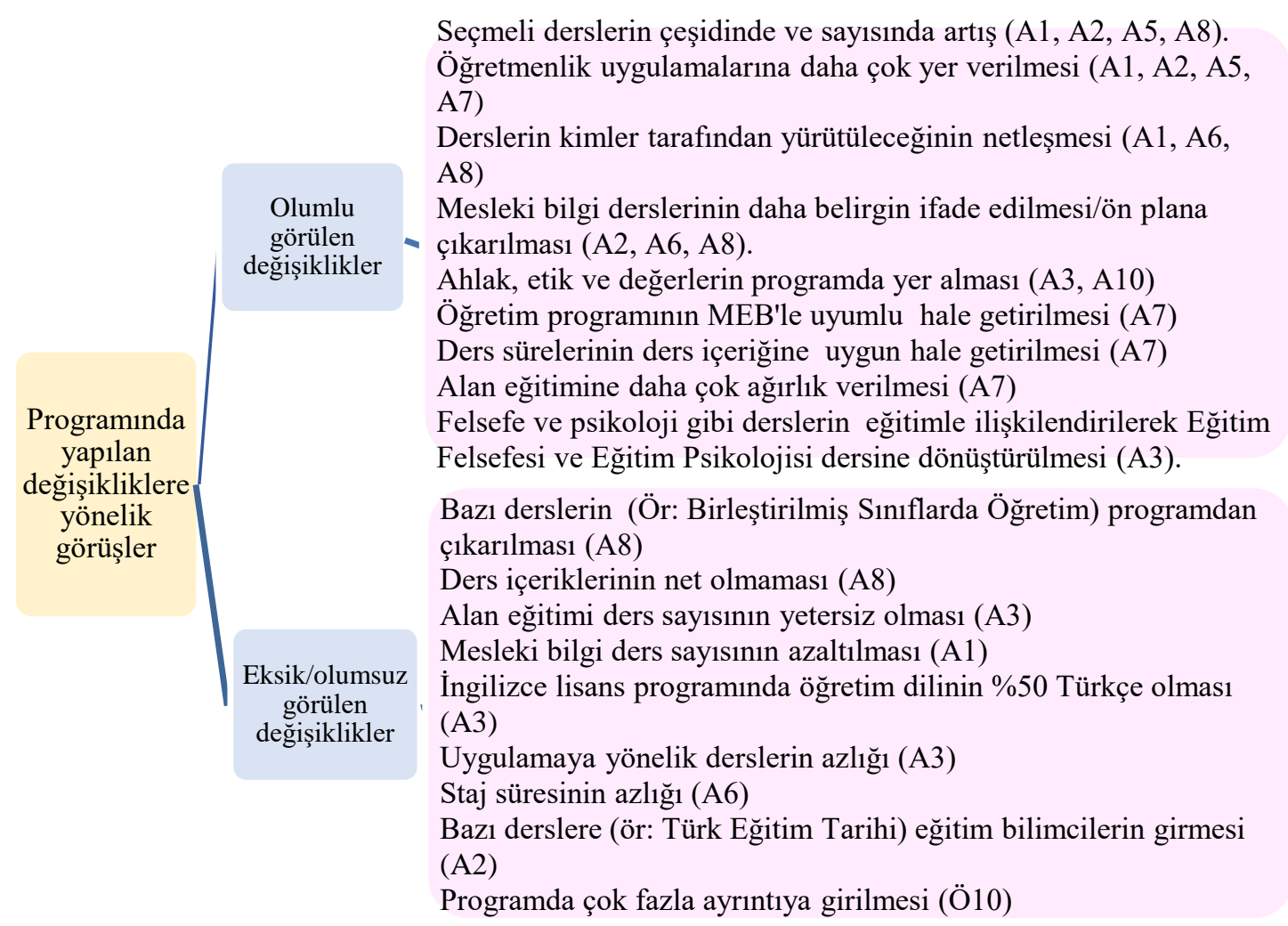

Şekil 2. Güncellenen Öğretmen Yetiştirme Programında Yapılan Değişikliklere Yönelik Görüşler

Öğretmen yetiştirme programında yapılan değişiklikler hakkında akademisyenler olumlu ve olumsuz görüş bildirmişlerdir. Programda eksik kalan yönlere dikkat çekmişlerdir. Akademisyenler seçmeli derslerin çeşidinde ve sayısındaki artış1 (A1, A2, A5, A8), uygulamaya daha çok yer verilmesini (A1, A2, A5, A7), derslere kimin gireceğinin netleşmesini (A1, A6, A8), eğitim derslerine daha fazla önem verilmesini (A2, A6, A8), ahlak, etik ve değerlerin programda yer almasinı olumlu olarak görmektedirler (A2, A3, A10). Konu ile ilgili A5 görüşünü "Güncellenen programda dikkatimi çeken iki önemli husustan birisi seçmeli ders sayısının ve çeşidinin artmasıdır. İkinci olumlu şey ise uygulamanın sayısı artmıştır." cümlesi ile belirtirken A6 "Olumlu. En azından kimin hangi derse girecek o netleşmiş oldu. Öğretmen yetiştirme sisteminin bel kemiği olan eğitim bilimciler daha fazla ön plana çıkmış oldu. Bence olumlu yönüdür." cümleleriyle belirtmiştir. Programda ahlak, etik ve değerlerle ilgili derslerin yer almasının olumlu olduğunu belirten A2'nin görüşü "Zorunlu eğitimde etik, ahlak ve değer eğitiminin olması iyi bir şey." şeklindedir. A7 öğretim programının MEB'le uyumlu hale getirilmesini, ders sürelerinin dersin içeriğine uygun hale getirilmesini, alan eğitimine daha çok önem verilmesini olumlu olarak karşlarken A3 felsefe, sosyoloji ve psikoloji gibi derslerin eğitimle ilişkilendirerek eğitim felsefesi, eğitim psikoloji olarak değiştirilmesini olumlu karşılamaktadırlar. Ö7 konu ile ilgili görüșünü " Eski programlarda alan bilgisi derslerinin ă̆ırlıkl almasının aksine yeni programda alan eğitimine önem verilmesini, ögretmenlik uygulaması dersinin daha fazla yer almasını, lisans programındaki alan eğitimi derslerinin içeriğinin MEB ögretim programı ile uyumlu hale getirilmesini ve derslerin sürelerinde yapılan düzenlemeleri oldukça yerinde olduğunu düşünüyorum.” şeklinde belirtirken A3 görüşünü "felsefe ve psikoloji gibi alanların daraltılarak eğitim felsefesi ve eğitim psikolojisi olarak tanımlamalarının doğru olduğunu düşünüyorum." şeklinde belirtmiştir.

Güncellenen eğitim programında bazı derslerin programdan çıkarılmasını ve ders içeriklerinin yeterince açık olmamasını Ö8 olumsuz olarak değerlendirmektedir. Konu ile ilgili 
Ö8'in görüşü "Sinıf öğretmenliği bölümünün olmazsa olmaz derslerinden birisi olan birleştirilmişs sinuflarda öğretim dersi yeni programda yer almamakta. Bu program için ciddi bir eksiklik diye düşünüyorum. Programlarda derse ilişkin genel çerçevenin çizilmiş olması içeriğinin net olmaması farklı uygulamalara yol açar.” şeklindedir. Ö3 ise güncellenen eğitim programında alan eğitimi dersi sayısının yetersiz olmasını, İngilizce lisans programında öğretim dilinin \%50 Türkçe olmasını olumsuzluk olarak belirtmiş ve Ö3 görüşünü “Alan eğitimi ders saylsl yetersiz. Derslerin \%50'sinde öğretim dilinin Türkçe olduğu görülmektedir. Uygulamaya yönelik ders sayısının yetersiz olduğu düşünülmektedir. " şeklinde ifade etmiştir. Olumsuz görüş bildiren A2'nin görüşü “Ĕgitim Tarihi dersine eğitim bilimcinin girmesini yanlış buluyorum. Uzmanlık alanına girmez. Bu tarihçinin işidir. Tarih eğitimcisinin olmadiğ ldurumlarda (bu dersin eğitim bilimlerinde uzmanlış bir ögretim eleman tarafindan yürütülmesi) daha uygun olur." şeklindedir. Programlarda yapılan değişikliklerin olumsuz olduğunu düşünen A10 görüşünü "Derslere iliş̧kin genel çerçeve çizilmiş ancak içerik net olarak belirlenmemiştir. Daha iyisini yapmak gerekirken daha ayrıntılı ve daha belirsiz bir programdır" ş̧eklinde ifade etmiştir.

Akademisyenler program ne kadar iyi hazırlanırsa hazırlansın öğretmen adaylarının atanma kaygısı ile KPSS baskısının programdan istenen sonuçların alınmasında engel teşkil edeceğini de belirtmişlerdir (A1, A2, A6). Bu konuda A6'nın görüşü “Bizim problemimiz şu program ne kadar iyi hazırlanırsa hazırlansin nihayetinde program ögrenciler üzerinde uygulanıyor 'ben atanacak mıyım' sorunu ve kaygısı kişilerde öğretmenlik kimliğinin oluşmasını engelliyor. Doğal olarak sizin de programdan istenilen sonuçları alamamanıza neden oluyor." şeklindedir.

\subsection{Güncellenen Öğretmen Yetiştirme Programının Öğretmen Yetiştirmeye Katkıları Hakkındaki Akademisyenlerin Görüşlerine İlişskin Bulgular}

Araştırmada yer alan üçüncü soruyla eğitim fakültesinde görevli akademisyenlerin güncellenen öğretmen yetiştirme programlarının öğretmen yetiştirmeye katkılarının neler olabileceği hakkındaki görüşleri belirlenmeye çalışılmıştır. $\mathrm{Bu}$ amaçla akademisyen görüşlerinden elde edilen bulgular Şekil 3'te verilmiştir. Araştırmada uzman olarak görüşüne başvurulan bazı akademisyenler (A4, A5, A7, A9) güncellenen öğretmen yetiştirme programının öğretmen yetiştirmeye katkılarının olacağını belirtirken A1, A2 ve A3 güncellenen öğretme yetiştirme programının öğretmen yetiştirmeye katkılarının sınırlı olacağını ifade etmiştir. Yeni programın yararlı olacağını düşünen A4 görüşünü, "Değiştirilen ögretmen yetiştirme programı uzun vadede etkili olacak ve yarar sağlayacaktır." seklinde ifade etmiştir. Konu ile ilgili A2'nin görüşü "Hiçbir katkısı olacağını düşünmüyorum." şeklinde iken, A3'ün görüşü "Bilişsim Teknolojileri adlı dersin yalnızca bir dönemle sınırlanmasının çağın ihtiyaçlarına cevap verecek nitelikte öğretmen yetiştirme noktasinda soru işareti oluşturduğunu düşünüyorum. ”şeklindedir. Olumlu görüş bildiren akademisyenlerin görüşleri ise Şekil 3'te verilmiştir.

$\begin{array}{cl}\begin{array}{c}\text { Güncellenen } \\ \text { öğretmen }\end{array} & \text { Kuramı uygulamaya aktaracak öğretmenler yetiştirilmesini sağlama } \\ \text { yetiştirme } & \text { Ö5,A7,A9) } \\ \text { progretmen adaylarının çok yönlü yetiştirilmesini sağlama (A5, Ö8) } & - \text { Öğretmen adaylarına nitelik kazandırmayı sağlama (A7, A9) } \\ \text { öğretmen } & \text { Yeniliğe uyum sağlayacak bireyler yetiştirilmesini sağlama (A4) } \\ \text { yetiştirmeye } & \text { Öğretmen adaylarına çağın gerektirdiği özellikleri kazandırma (A6) } \\ \text { katkıları } & \text { Öğretmen adaylarına mesleki beceri, tutum ve duyuşsal özellikleri kazandırma (A10). }\end{array}$

Şekil 3. Güncellenen Öğretmen Yetiştirme Programının Öğretmen Yetiştirmeye Katkıları

Şekil 3'e bakıldığında akademisyenlerin güncellenen öğretmen yetiştirme programının öğretmen yetiştirmeye katkıları hakkındaki bazı görüşleri; teoriyi pratiğe aktaracak öğretmenler yetiştirilmesini sağlama (A5, A7, A9), öğretmenlerin çok yönlü yetişmesini sağlama ve öğretmen adaylarına nitelik kazandırmayı sağlamadır. A5'in konu ile ilgili görüşü "Kuramı 
uygulamaya taşıyacak öğretmenlerin yetişmesine katkl sağlayacaktır diye düşünüyorum. Ayrıca farklı seçmeli dersler ile ögretmen adaylarının çok yönlü gelişimine katkl sağlayacaktır diye tahmin ediyorum." şeklinde iken A7'nin görüşü "Yapılan değişikliklerle çok daha nitelikli ve sahip olduğu bilgileri uygulamada işlevsel olarak kullanabilen ögretmenlerin yetişebileceğini düşünüyorum." şeklindedir. A4 "Yeniliğe uyum sağlamanın, uzun vadede yarar getireceğine inanıyorum." şeklindeki cümlesi ile konu hakkındaki görüşlerini belirtmiştir. Programın çağın ihtiyaç duyduğu öğretmen yetiştirmeyi amaçladığ 1 A6 "Program hazırlama gerekçesinde de belirtildiği gibi çağın ihtiyaç duyduğu öğretmeni yetiştirmeyi öngörmektedir.” cümlesi ile vurgulamıştır. Güncellenen öğretmen yetiştirme programının öğretmen adaylarına olumlu katk1lar sağlayacağını düşünen A10 görüşünü "Mesleki beceri, tutum ve davranışlar ve duyusal özellikler bakımından olumlu yönde katkı sağlayacaktır." şeklinde ifade etmiştir.

\subsection{Akademisyenlerin Öğretmen Yetiştirme Programlarının İyileştirilmesine Yönelik Önerilerine İlişkin Bulgular}

Araştırmanın cevap aradığı diğer bir sorunun amacı, ise 2018'den sonra daha nitelikli öğretmen yetiştirme programının geliştirilmesi için akademisyenlerin önerilerini belirlemektir. $\mathrm{Bu}$ amaçla elde edilen bulgular Şekil 4'te verilmiştir.

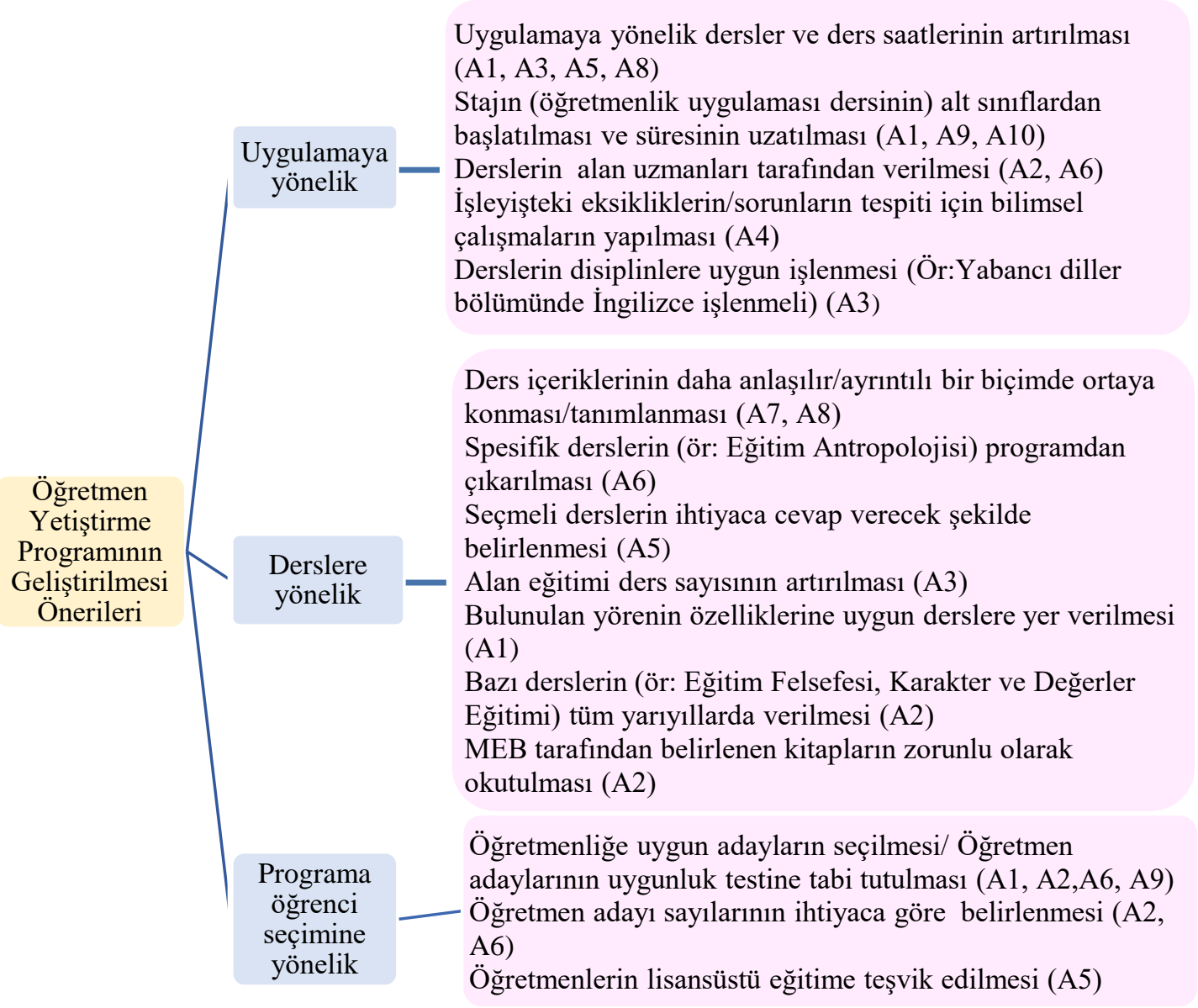

Şekil 4. Öğretmen Yetiştirme Programının Geliştirilmesine Yönelik Öneriler

Şekil 4 incelendiğinde akademisyenlerin öğretmen yetiştirme programının geliştirilmesine yönelik önerileri programın uygulanmasına, derslere, programa öğrenci seçimine yönelik olmak üzere üç tema altında gruplandırılmıştır. Akademisyenlerin uygulamaya yönelik önerileri; uygulamaya yönelik dersler ve saatleri artırılmalı (A1, A3, A5, A8), staj alt sınıflardan başlatılmalı ve süresi uzatılmalı (A1, A9, A10), dersler alanın uzmanları tarafından 
verilmeli (A2, A6), işleyişteki eksikliklerin tespiti için bilimsel çalışmalar yapılmalı (A4), dersler disiplinlere uygun işlenmeli (A3) şeklindedir. Konu ile ilgili A1'in görüşü “ Uygulamaya yönelik derslerin artırılması, staja başlamak için 4. sınıf çok geç alt sınıflarda bu uygulamanın başlaması." şeklindedir. Derslerin uzmanlar tarafından verilmesini "Program değişstikten sonra programın hayat bulacağı akademisyen sorununun çözülmesi lazım. Örneğin Eğitim Sosyolojisi, Eğitim Felsefesi ve Eğitim Tarihi derslerini anlatacak hoca yokken bu dersleri koyuyorsunuz." cümlesi ile açıklamıştır. Bilimsel çalışmaların yapılmasını A4 "Gelecekte yapılacak olan kongre, sempozyum, çalıştay vb. bilimsel toplantıların gündeminde kalmaya devam etmesi, eksik ya da sorunların tespiti için yapılacak bilimsel çalışmaların teşvik edilmesi programı daha da başarılı hale getirecektir." ş̧eklinde vurgulamıştır. Yabancı dil öğretmenliği lisans programına ilişkin düşüncesini A3 "Derslerin çoğunlukla hedef dilde (İngilizce) işlenmesi gerekir." şeklindeki cümlesi ile belirtmiştir.

Akademisyenler derslerle ilgili yapılması gereken önerileri; ders içerikleri ayrıntılı bir şekilde belirtilmeli (A7, A8), spesifik dersler programdan kaldırılmalı (A6), seçilen seçmeli dersler ihtiyaca cevap vermeli (A5) ve yörenin özelliklerine uygun olmalı (A1), alan dersleri artırılmalı (A3), baz1 dersler her dönem verilmeli (A2), MEB tarafından belirlenen kitaplar zorunlu olarak okutulmalı (A2) şeklindedir. Ders içerikle ilgili olarak A7'nin görüşü "Ders içeriklerinin daha anlaşıllı (detaylı) olarak ortaya konması gerektiğini düşünüyorum." şeklinde iken, spesifik derslerle ilgili A6'nın görüşü “ Başka bir problem eğitim antropolojisi diye bir ders var. Bu dersin ne hocası ne de kaynă̆ var. Spesifik bir konuda özellikle Anadolu'da bu dersi anlatacak hocayı bulmak çok zor. Ona göre dersler seçilmeli veya bu dersler seçmeli olabilir." şeklindedir. Seçilen derslerin ihtiyaca cevap vermesi ile ilgili A5 görüşünü “ Seçmeli derslerin gerçekten seçmeli ders ruhuna uygun olması gerekir." cümlesi ile ifade ederken A1 yörenin özelliklerinin göz önünde bulundurulması gerektiğini "Genel kültür ve genel yetenek alanlarında üniversitelerin bulunduklar yörenin özellikleri de göz önünde bulundurulmall." cümlesi ile ifade etmiştir. A2'nin bazı derslerin her dönem verilmesi ile ilgili önerisi "eğitim felsefesi, Türk Eğitim Tarihi, Eğitimde Ahlak ve Etik, Karakter ve Değer Eğitimi derslerinin istisnasız her dönem dörder saatlik bir zaman dilimiyle verilmesi gerektiğini düşünüyorum." şeklinde iken, kitap okutulması ile ilgili önerisi “MEB'in belirleyeceği belirli kitaplar (Ör: 100 temel eser tarzl) okutulmadan mezun edilmemeli." şeklindedir.

Akademisyenlerin üzerinde durduğu önerilerden biri de programa öğrenci seçimine yöneliktir. Akademisyenler öğretmenliğe seçerek öğrenci alınmasını önermektedir (A1, A2, A6, A9). Ayrıca akademisyenler ihtiyaca göre öğretmen aday sayılarının belirlenmesini (A2, A6) ve öğretmenlerin yüksek lisans yapmaları için imkân sağlanmasını (A5) önermektedirler. Konu ile ilgili A1 görüşünü “ Öğretmen adaylarının seçiminde psikolojik testler yapılarak mesleğe yatkınlı̆ııın belirlenmesi." cümlesi ile ifade ederken, A6 ihtiyaca göre aday sayılarının belirlenmesi ile ilgili görüşünü "Bir istihdam politikası oluşturularak ihtiyaç kadar ögrretmen adayı yetiştirmeli." şeklindeki cümlesi ile ifade etmiştir. Yüksek lisans yapma ile ilgili A5'in görüşü "Öğretmenlik lisans diploması alındıktan sonra mesleğe girildiğinde veya hizmet içi dönemde ögretmenlerin yüksek lisans yapması teşvik edilmelidir." şeklindedir.

\section{TARTIŞMA VE SONUÇ}

$\mathrm{Bu}$ araştırmada öğretmen yetiştirme programının değişme nedenleri; önceki programdan kaynaklanan sorunlar, politik nedenler ve nitelikli öğretmen yetiştirme arayışı şeklinde olduğu sonucuna ulaşılmıştır. Alanyazında yapılan çalışmalar bu araştırmanın sonucuna destekler biçimde programların değiştirilmesine bir önceki programdan kaynaklanan sorunların (Dinç ve Doğan, 2010; Gerek, 2006; Ünsal, vd. 2019), değişimin hızlı gerçekleşmesinin ve yayılmasının programların çağın gereksinimine cevap verememesinin (Gülersoy, 2010; Seferoğlu, 2007; Ünsal, vd. 2019) neden olduğunu vurgulamaktadır. Ayrıca araştırmanın politik nedenlerle ilgili sonucu Ünsal ve diğerlerinin (2019) yaptığı çalışmanın sonucunu desteklemektedir. Nitelikli 
öğretmen yetiştirme süreçlerinin kalitesini artırarak daha nitelikli ve çağa uygun, çok yönlü, donanımlı öğretmen yetiştirme arayışı programın değişme nedenleri arasında yer almaktadır. Akademisyenlerin öğretmen yetiştirmede nitelik kavramına vurgu yapmalarına dünyada öğretmen eğitiminde ve yeterliklerinde niteliğin (Erdem, 2015) ön plana çıkmasının, konferanslarda ve raporlarda öğretmenlerin niteliğine ilişkin tartışmalarının yapılmasının (Yıldırım, 2011) etkisi olduğu söylenebilir. Öğretmen yetiştirme sürecine bakıldığında özellikle 1990'lı yılların sonuna kadar öğretmen yetiştirmede arz-talep dengesi tutturulamadığı için niteliğin niceliğe feda edildiği görülmektedir (Saylan, 2013). En azından 2018 öğretmen yetiştirme programındaki değişikliğin nedenine ilişkin akademisyenlerin niteliğe yönelik vurgu yapmaları niteliğin niceliğe feda edilmemesi adına olumlu karşılanabilir.

$\mathrm{Bu}$ araştırmada akademisyenler dünyaya ayak uydurma çabasının öğretmen yetiştirme programının değişmesinde etkili olduğunu belirtmişlerdir. Öğretmen yetiştirme ile ilgili geçmişten günümüze ulusal ve uluslararası gelişmelere göre öğretmen yetiştiren fakültelerin programlarında birçok değişiklik yapılmıştır (MEB, 2017). Bu değişikliklerin yapılması, öğretim programlarının dinamik yapısının gereği olarak düşünülebilir. Günümüzde, toplumsal değişim ve dönüşünün çok hızlı gerçekleşmesi, bilginin niceliğinde ve niteliğinde artışın olması, teknolojinin hayatın her alanında daha fazla kullanılmaya başlanması ile bilim dünyasında yaşanan gelişmeler, akademisyenlerin öğretim programların değişimini dünyada ayak uydurma çabasının bir sonucu olarak değerlendirmelerine neden olmuş olabilir. Akademisyenler programın değişimine Bologna sürecine uyum çabasının da etkili olduğunu belirtmişlerdir. Yurdakal (2018)'un daha önceki programda Erasmus, Mevlâna ve Farabi değişim programlarında, çift ana dal uygulamalarında, yatay geçişlerde aksaklıklar yaşandığını ve güncellenen programla bu aksaklıkların giderildiğini belirtmesi, bu araştırmanın öğretmen yetiştirme programlarının değişmesine Bologna sürecine uyumun da etkili olduğuna dair sonucunu desteklemektedir.

Güncellenen öğretmen yetiştirme programlarına yönelik akademisyenler, zorunlu seçmeli ders sayısının arttırılması, eğitim bilimlerinin daha fazla ön plana çıkarılması, uygulamaya yönelik adımlar atılması, programın çok yönlü öğretmen yetiştirmeyi öngörmesi, hangi derse kimin gireceğinin netleşmesi şeklinde birçok olumlu görüş bildirmişlerdir. Alanyazında yapılan araştırmalar bu araştırmanın sonucunu destekler şekilde 2018 programının meslek bilgisini önceleyen bir yaklaşımla hazırlandığını belirtmişlerdir. Ayrıca şeçmeli ders sayılarının artırılması ve çeşitlendirilmesi sonucu bu araştırmanın sonucunu destekler niteliktedir (Akarsu vd., 2020; Aykaç ve Stebler, 2019; Dağtekin ve Zorluoğlu, 2019).

Akademisyenlerin bu görüşlerini belirtmelerinde "Eğitim Sosyolojisi”, "Eğitim Felsefesi”, "Türk Eğitim Tarihi" gibi derslerin yeni programda tüm alanlara zorunlu ders olarak konulmasının bir etkisi olabilir. "Eğitim Sosyolojisi”, "Eğitim Felsefesi”, “Türk Eğitim Tarihi” gibi derslerin öğretmen adaylarına birçok katkısının olması beklenmektedir. Örneğin Eğitim Felsefesi dersi, öğretmen adaylarına eğitim olgusuna daha bütünsel ve analitik düzlemde bakmanın yanında, eğitimin gerekliliğini dair farkındalık kazandırarak rehberlik etmektedir. Toplumun ve bireylerin hangi yönde ve nasıl şekilleneceğini, eğitimin nasıl yapılacağını, hangi yöntemlerin, hangi yaklaşım çerçevesinde kullanılacağını göstermesi bakımından Eğitim Felsefesi önemlidir (Doğanay, 2011). Eğitim Sosyolojisi ise, öğretmen adaylarına, toplumsal değişimin eğitim sistemi, veli ve öğrenciler üzerindeki etkilerini fark etmelerini sağlamada, toplumsal değişimin getirdiği öğretmen rollerinin ve öğrenci sorumluluklarının neler olduğunun anlaşılmasında, eğitimin anlamı ve işlevinde nelerin değiştiğinin tespit edilmesinde katk1 sağlayacaktır (Ünsal ve Korkmaz, 2018). Bununla birlikte, Türk Eğitim Tarihi dersi sayesinde öğretmen adayları Türk eğitim tarihindeki dönemleri ve bu dönemlerdeki eğitimin amacını, programını, öğretim yöntemlerini, disiplinini, Türk eğitim tarihindeki dönemlerde nasıl bir insan tipi yetiştirilmek istendiği, Türk eğitim sisteminde yaşanan eğitim sorunlarının neler olduğunu, Türk eğitim tarihindeki olgu ve olayları sorgulamayı öğrenecektir (Erdem, 2013). Ancak bu derslerin programa konulmasıyla beraber üzerinde durulması gereken esas soru bu dersleri kimin yürüteceği ile ilgilidir. Çünkü dersleri okutacak olan öğretim üyelerinin uzmanlıkları, mesleki 
gelişim durumları, yeterliği, bu derslere bakış açıları nitelikli öğretmen yetiştirme açısından önemli birer faktördür (Şendağ ve Gedik; 2015; Baki, 2010; Seferoğlu, 2009). Eğitim Sosyolojisi, Eğitim Felsefesi, Türk Eğitim Tarihi dersleri MB kodu ile eğitim bilimi alanında uzmanlaşmış öğretim elemanları tarafından yürütülecek dersler olarak görülse de eğitimin sosyal ve tarihi temelleri bölümünün dışında doktorasını eğitim bilimleri alanında yapan uzmanlar yüksek lisans ve doktora eğitimleri boyunca Eğitim Sosyolojisi, Eğitim Felsefesi, Eğitim Tarihi gibi dersleri ya çok az görmüş ya da hiç görmemişlerdir. Bu durumda öğretim üyelerinin bu derslere ilişkin yetkinlikleriyle birlikte bu derslerden beklenen amaçların ne kadarının gerçekleştirilebileceğinin bir tartışma konusu oluşturacağı söylenebilir.

Akademisyenler yenilenen öğretmen yetiştirme programları sayesinde kimin hangi dersi yürüteceği konusundaki belirsizliğin giderildiğini belirtmişlerdir. Akademisyenlerin böyle düşünmelerinde, önceki programda yer alan "Eğitimde Araştırma Yöntemleri” ve "Öğretim Teknolojileri ve Materyal Geliştirme" derslerinin alan eğitimi uzmanları mı yoksa eğitim bilimleri alanında uzmanlaşan öğretim elemanları tarafından mı yürütülmesi gerektiğine dair belirsizliğin neden olduğu söylenebilir. Bu belirsizliğin önüne geçmek için yenilenen öğretim programında, "Bilimsel Araştırma Yöntemleri” dersinin adı "Eğitimde Araştırma Yöntemleri", "Öğretim Teknolojileri ve Materyal Geliştirme" dersinin adı ise "Öğretim Teknolojileri" olarak değiştirilerek her iki ders de MB kodlu ders kategorisine eklenmiş ve söz konusu derslerin eğitim bilimleri alanında uzmanlaşan öğretim elemanları tarafından yürütüleceği açıkça belirtilmiştir (YÖK, 2018).

Araştırmanın diğer bir sonucu ise, güncellenen öğretmen yetiştirme programının kuramsal bilgiyi uygulamaya aktaracak öğretmenlerin yetiştirilmesine katkı sağlayacağı şeklindedir. Akademisyenlerin böyle düşünmelerinde, önceki programda yer alan ancak yeterince işlevsel ve etkili olmadığı düşünülen “Okul Deneyimi” dersinin çıkarılarak söz konusu ders ile Öğretmenlik Uygulaması derslerine ait içeriklerin birleştirilmesi ile tasarlanan Öğretmenlik Uygulaması 1 ve Öğretmenlik Uygulaması 2 derslerinin tüm öğretmen yetiştirme lisans programlarının yedinci ve sekizinci yarıyıllarına zorunlu ders olarak tanımlanması etkili olmuş olabilir. Öğretmenlik mesleği doktorluk ve mühendislik gibi bir uygulama mesleğidir (Alter ve Coggshall, 2009; Grossman ve Mc Donald, 2008; Kazu ve Yenen, 2015). Bu açıdan Öğretmenlik Uygulamas1 derslerinin, öğretmen adaylarına somut yaşantılar sunarak kuram ve uygulama bütünlügünü sağlama, mesleği benimseme, mesleği daha iyi anlamanın yanında (Oğuz, 2004), öğretmenöğrenci- idare ile daha etkili iletişim geliştirme; öğretim stratejilerini, yöntemlerini, ve öğrenme prensiplerini sınıf ortamına aktarabilme, sınıftaki disiplin problemleri ile nasıl başa çıkılacağına yönelik deneyim elde etme gibi birçok konuda katkısı bulunmaktadır (Akbar, 2001; Gujjar, Naoreen, Saifive Bajwa, 2010; Nwanekezi, Okoli ve Mezieobi, 2011). Bu katkılar göz önünde bulundurulduğunda güncellenen öğretmen yetiştirme programlarında öğretmenlik uygulamas1 dersine yönelik değişikliklerin olumlu sonuçlar doğuracabileceği söylenebilir. Yurdakal (2018), değişen Sınıf Öğretmenliği lisans programının incelenmesine yönelik çalışmasında akademisyenlerden farklı olarak öğretmenlik uygulaması dersinin sadece iki dönemde değil üç veya dört dönemde verilmesi gerektiğini belirtmiştir. Bu durum bu araştırma için de geçerlidir. Akademisyenler uyguma dersinin süresi artırılmış olsa da yine de yeterli olmadığını belirtmişlerdir.

Bazı derslerin programdan çıkarılması, ders içeriklerinin net olmaması, İngilizce lisans programında öğretim dilinin \%50 Türkçe olması, uygulamaya yönelik derslerin azlığı, staj süresinin azlığı programda akademisyenler tarafından belirtilen olumsuzluklardır. Akademisyenler atanma kaygısı ve KPSS baskısının programdan istenilen sonuçların alınmasında engel teşkil edeceğini de belirtmişlerdir. Öğretmenlerin istihdamında çok çeşitli nedenlerden dolayı arz-talep dengesinin kurulamaması (Aydın, Sarıer, Uysal, Aydoğdu ve Özer, 2014; Özoğlu, 2010) ve eğitim fakültelerinin okullar için gerekli olan öğretmen ihtiyacından fazla mezun vermesi nedeniyle MEB, atanacak öğretmenleri belirlemek üzere Kamu Personeli Seçme Sınavına (KPSS) katılımı zorunlu kılmıştır (Atav ve Sönmez, 2013; Bahar, 2006; Baştürk, 2008). 
Bu sınavın varlığı, bu araştırmada da akademisyenlerin vurguladığı gibi eğitim programlarında istenilen sonuçların alınmasında engel teşkil edebilmektedir. Çünkü öğretmen adayları KPSS'den dolayı stres yaşamakta, fakültede uygulanan programları tam anlamıyla takip edememekte ve bu sebeple kendi alanlarına yoğunlaşamamakta, hatta bu durumdan dolayı öğretmen adaylarının uygulama okullarında verimlilikleri düşmektedir (Eraslan, 2006; Eraslan, 2009). KPSS'nin öğretmen yetiştirme programlarının uygulanmasındaki olumsuz etkisi, Yıldırım'ın (2011) da vurguladığı gibi, KPSS öğretmen yetiştirme programlarında yer alan derslere verilen önemin öğretme ve öğrenme süreçlerini önemli ölçüde belirleyen bir etken haline gelmesinden kaynaklanmaktadır. Doğal olarak öğretmenler adayları için önemli ve öncelikli dersler, KPSS'de çok soru çıkan dersler olmakta; diğer dersler ise görece olarak ikinci plana atılmaktadır. Akademisyenler öğretmen adaylarının atanma kaygısı yaşamalarının programda istenilen sonuçların alınmasında engel teşkil eden diğer bir unsur olduğunu belirtmişlerdir. Akademisyenlerin böyle düşünmelerinde atama bekleyen öğretmen aday sayısının fazlalığı, belli branşlarda öğretmen alımlarının oldukça az olmasının bir etkisi olabilir. Öğretmen adaylarındaki atanma kaygısının, bu adayların mesleki kimlik oluşturma, mesleki ruh kazanma ve mesleğe yönelik olumlu tutum geliştirmelerini olumsuz yönde etkileyebileceği söylenebilir. Bu olumsuz etki öğretmen adaylarının öğretim programında yer alan dersleri tam anlamıyla içselleştirmemelerine ve programın amaçlarını tam anlamıyla benimsememelerine de neden olabilir. Akademisyenler öğretmen yetiştirme programlarına ilişkin gözlemledikleri olumsuzlukların giderilmesi hususunda uygulamaya yönelik, derslere yönelik ve programa öğrenci seçimine yönelik birçok öneri sunmuşlardır.

\section{ÖNERILER}

Bu araştırma verileri Anadolu'da bir üniversitede farklı unvanlarda görev yapan 10 gönüllü akademisyenin 2018 yılında güncellenen öğretmen yetiştirme lisans programlarına ilişkin görüşleri ile sınırlıdır. Bu üniversitede eğitim fakültesinde olabilecek tüm bölümler açık değildir. $\mathrm{Bu}$ durum akademisyenlerin görüşlerini sınırlandırmış olabilir. Araştırma sonuçlarına göre aşağıdaki öneriler getirilmiştir.

- $\quad \mathrm{Bu}$ araştırmada akademisyenler uygulamaya ve derslere yönelik bir çok görüş ve öneri sunmuşlardır. Programın daha da işlevsel olabilmesi için akademisyenlerin sundukları öneriler program geliştiricileri tarafından dikkate alınarak yerine getirilmelidir.

- $\quad \mathrm{Bu}$ araştırmada programın uyuglayıcıları olan akademisyenlerin programı benimsemeleri için araştırmada belirttikleri olumsuzluklar giderilebilir.

- Araştırmadaki akademisyenlerin vurguladığı Eğitim Antropolojisi, Türk İşaret Dili gibi spesifik dersler öğrenciler tarafından talep edilmemişse ve ilgili anabilim dalında bu derleri yürütücek nitelikte öğretim elemanı bulunmaması halinde söz konusu dersler programa dahil edilmemelidir.

- Uygulama dersleri ve öğretmenlik uygulaması dersinin sayısı ve/veya süresi artırılabilir.

- İşleyişteki eksikliklerin/sorunların tespiti için bilimsel çalışmalar daha geniş kapsamlı ve çok daha fazla katılımcı ile yapılabilir.

- $\quad \mathrm{Bu}$ çalışma nitel olarak yürütülmüş olup daha geniş örneklem grubu ile nicel çalışmalar yapılabilir.

- Program çevresinde şekillenen öğretmen mesleki yeterliklerine ilişkin araştırmalar yapılabilir. 


\section{KAYNAKÇA}

Abazaoğlu, İ., Yıldırım, O. ve Yıldızhan, Y. (2016). Geçmişten günümüze Türk eğitim sisteminde öğretmen yetiştirme. Uluslararası Türk Eğitim Bilimleri Dergisi, 4(6), 143-160.

Ada, S. ve Ünal, S. (1999). Öğretmenlik mesleğine giriş. Marmara Üniversitesi Teknik Eğitim Fakültesi Yayın No:13. İstanbul: Marmara Üniversitesi Teknik Eğitim Fakültesi Döner Sermaye İsletmesi Matbaası.

Ağçam, R. \& Babanoğlu, M. P. (2020). A SWOT analysis of English language teacher training curriculum. Harun Şahin (Ed.), In educational sciences: Theory, current researches and new trends, pp. 209-221.

Akarsu, A. H. , Y1lmazer, A. ve Geçit, Y. (2020). Sosyal bilgiler öğretmen eğitimi programlarının yapısı: 2006-2018 programlarının karşılaştırılması. Mehmet Akif Ersoy Üniversitesi Ĕgitim Fakültesi Dergisi, (56), 23-60.

Akay, C. ve Ültanır, E. (2010). Andragojik temellere dayali kolaylaştirilmiş okuma-yazma eğitimi (KOYE) sürecine yönelik koye eğiticilerinin görüşleri. Mersin Üniversitesi Ĕ̈itim Fakültesi Dergisi, 6(2), 75-88. doi: 10.17860/efd.82884

Akbar, R.A. (2001). A study of teaching practice of prospective secondary school teachers and development of a teaching practice model. Un published PhD Thesis. Rawalpindi Arid Agricultural University

Akdemir, A. S. (2013). Türkiye'de öğretmen yetiştirme programlarının tarihçesi ve sorunları. Turkish Studies, 8(12), 15-28.

Akyüz, Y.(2001). Başlangıçtan 2001'e Türk eğitim tarihi. İstanbul: Alfa Yayınları.

Alter, J. \& Coggshall, J. G. (2009). Teaching as a clinical practice profession: İmplications for teacher preparation and state policy. NYCC/TQ Center Teaching as a Clinical Practice Profession. 1-12.

Aslan, N. (2015). Öğretmenliğin meslek olarak seçilmesinde etkili olan temel unsurlar. International Journal of Social Science, 37(1), 53-64. Doi: http://dx.doi.org/ 10.9761/ JASSS2958.

Atav, E. ve Sönmez, S. (2013). Öğretmen adaylarının Kamu Personeli Seçme Sınavına (KPSS) ilişkin görüşleri. Hacettepe Eğitim Fakültesi Dergisi, Özel Sayl, 1, 1- 13.

Aydın, A. (1998). Eğitim fakültelerinin yeniden yapılandırılması ve öğretmen yetiştirme sorunu. Kuram ve Uygulamada Eğitim Yönetimi Dergisi, 4(3), 275-286.

Aydın, A., Sarıer, Y., Uysal, Ş., Aydoğdu Özoğlu, E. ve Özer, F. (2014). Türkiye'de öğretmen istihdamı politikalarının değerlendirilmesi. Kuram ve Uygulamada Ĕgitim Yönetimi, 20(4), 397-420. doi: 10.14527/kuey.2014.016.

Aykaç, N. ve Stebler, M. Z. (2019). 2018 Türkçe öğretmenliği lisans programının öğretim elemanlarının görüşleri doğrultusunda değerlendirilmesi. Journal of Language Education and Research, 5(2), 116-138. doi: 10.31464/jlere.610269

Bahar, H. H. (2006). KPSS puanlarının akademik başarı ve cinsiyet açısından değerlendirilmesi. Eğitim ve Bilim, 31(140), 68-74.

Baki, A. (2010). Öğretmen eğitiminin lisans ve lisansüstü boyutlardan değerlendirilmesi. İnönü Üniversitesi Ĕ̈itim Fakültesi Dergisi, 11(1), 15-31.

Baştürk, R. (2008). Fen ve teknoloji alanı öğretmen adaylarının Kamu Personeli Seçme Sınavı başarılarının yordanması. Illkögretim Online, 7(2), 323-332. 
Berg L. B ve Lune, H. (2015) Sosyal Bilimlerde nitel araştırma yöntemleri (Çev. Ed. H. Aydın) Ankara: Eğitim Yayınevi

Berg, B.L. (2001). Qualitative research methods for the social sciences. Boston: Ally and Bacon.

Berk, Ş. (2014). Hayat ağacının toprağı: Eğitim. Kamuda Sosyal Politika, 29, 101-106.

Boudersa, N. ( 2016 ). The importance of teachers' training and professional development programs in the Algerian educational context: Toward informed and effective teaching practices, Expériences Pédagog iques, http://exp-pedago.ens-oran.dz.

Center for Education National Research Council (2001). Educating teachers of science, mathematics, and technology. Washington: National Academy Press.

Creswell, J. W. (2016). Nitel araştırma yöntemleri, beş yaklaşıma göre nitel araştırma ve araştırma deseni. (Çeviri Ed. M. Bütün \& S. B. Demir) Ankara: Siyasal Kitabevi

Çapa, Y. ve Çil, N. (2000). Öğretmen adaylarının öğretmenlik mesleğine yönelik tutumlarının farklı değişkenler açısından incelenmesi. Hacettepe Üniversitesi Eğitim Fakültesi Dergisi, 16, 69-73.

Çetin, A. (2017). Özel dershanelerden resmi okullara atanan ilköğretim fen bilimleri ögretmenleri üzerine bir durum çalışması. Yayınlanmamış Doktora Tezi, Çukurova Üniversitesi, Adana.

Dağtekin, A. ve Zorluoğlu, S. L. (2019). Güncellenen fen bilgisi öğretmenliği lisans programi hakkindaki akademisyenlerin görüşleri. SDU International Journal of Educational Studies, 6(1), 31-35. doi: 10.33710/sduijes.538114

Darling H., L. (2000). Teacher quality and student achievement: A review of state policy evidence. Education Policy Analysis Archives, 8(1), 1-44.

Demir, N. , Ertem Akbaş, E. ve Gök, M. (2021). Yenilenen ilköğretim matematik öğretmenliği lisans programı ile ilgili öğretim elemanlarının görüşleri . Yüzüncü Yll Üniversitesi Eğitim Fakültesi Dergisi , 18(1) , 70-105 . doi: 10.33711/yyuefd.859490

Demir, Ö ve Acar, M. (1996). Sosyal bilimler sözlüğ̈̈. Ankara: Vadi Yayınları

Dinç, E. ve Doğan, Y. (2010). İlköğretim ikinci kademe sosyal bilgiler öğretim programı ve uygulanması hakkında öğretmen görüşleri. Sosyal Bilgiler Eğitimi Araştırmaları Dergisi, $1(1), 17-49$.

Doğanay, A (2011). Hizmet öncesi öğretmen eğitiminin öğretmen adaylarının felsefi bakış açılarına etkisi. Eğitim ve Bilim Dergisi, 36(161), 332-348.

Duran, H. (2001). Bir meslek olarak öğretmenlik. Eskişehir: Anadolu Üniversitesi

Eraslan, A. (2009). İlköğretim matematik öğretmen adaylarının "Öğretmenlik Uygulaması" üzerine görüşleri. Necatibey Eğitim Fakültesi Elektronik Fen ve Matematik Eğitimi Dergisi, 3(1), 207-221.

Eraslan, L. (2006) Öğretmenlik mesleğine girişte kamu personeli seçme sınavı (KPSS) yönteminin değerlendirilmesi. International Journal of Human Sciences 1(1), 1- 31.

Erdem, A. R. (2013). “Türk Eğitim Tarihi” dersinin öğretmen adaylarının eğitimi açısından önemi. M. Aydın (Ed.), Prof. Dr. Önder Göçgün'e Armağan içinde (s. 441-474). Denizli: Pamukkale Üniversitesi Yayınları.

Erdem, A. R. (2015). Türkiye'deki öğretmen yetiştirmenin [a], [b], [c]'si. Journal of Teacher Education and Educators, 4(1), 16-38.

Ergün, M. (1987). Türkiye' de öğretmen yetiştirme çalışmalarının gelişmesi. Hacettepe Üniversitesi Eğitim Fakültesi Dergisi, 2, 10-18. 
Gerek, Ö. (2006). Sınıf ögrretmenlerinin yeni ilköğretim programı hakkındaki görüş değerlendirme ve yeterlilikleri üzerine bir araştırma. Yayınlanmamış yüksek lisans tezi, Selçuk Üniversitesi Sosyal Bilimler Enstitüsü, Konya.

Gömleksiz, M. N. (2004). Öğretmenlik mesleğinin nitelikleri. M. Taşpınar (Ed.), Eğitim bilimine giriş̧ (s. 152). Elazığ: Üniversite Kitabevi.

Grossman, P. \& McDonald, M. (2008). Back to the future: Directions for research in teaching and teacher education. American Educational Research Journal, 45 (1), 184-205.

Guerriero, S. (2017). Pedagogical knowledge and the changing nature of the teaching profession, OECD Publishing, Paris http://dx.doi.org/ 10.1787/9789264270695 adresinden 04.04.2019 tarihinde erişilmiştir.

Gujjar, A. A., Naoreen, S.S., \& Bajwa, M.J. (2010). Teaching practice: Problems and sssues in Pakistan. International Online Journal of Education, 2 (2), 339-361.

Guskey, T. R. (2002). Professional development and teacher change. Teachers and Teaching: Theory and practice, 8(3), 381-391.

Gülersoy, A. E. (2010). Eski ve yeni 9-10. sınıf coğrafya öğretim programlarının değerlendirilmesi. Buca Eğitim Fakültesi Dergisi, 22, 163-173.

Hanushek, E.A., Kain, J. F., \& Riykin, G.(1998). Teachers schools and academic achievement, NBER Working Paper Series, No. 6691, National Bureau of Economic Research, Cambridge, MA.

Hargreaves, L. (2009). The status and prestige of teachers and teaching. In. L.J. saha And A.G.

Ingersoll, R.M. \& Perda, D.(2008). The status of teaching as a profession. Schools and Society: A Sociological Approachto Education. 12, 106-118.

Johnson, B. \& Christensen, L. (2012). Educational research quantitative, qualitative and mixed approaches. London: SAGE.

Karsl1, M.D. ve Güven, S.(2011). Öğretmen yetiştirme politikaları. S. A. Kilimci (Ed.) Türkiye'de ögretmen yetiştirme içinde (s.53-83). Ankara: Pegem Akademi.

Kazu, İ.Y. ve Yenen, E.T. (2015) Öğretmen yetiştirme sisteminde öğretmenlik uygulamalarının temel alındığı bir model önerisi. Researcher: Social Sciences Studies (RSSS), 5, 26-34.

Kilimci, S. A.(2011). Türkiye'de öğretmen olmak. S. A. Kilimci (Ed.) Türkiye'de öğretmen yetiştirme içinde (s. 117-132). Ankara: Pegem Akademi.

Köktaş, S., K. (2003). Öğretmenlik mesleğine giriş. Ankara: Nobel Yayınları.

MEB Öğretmen Yetiştirme ve Eğitimi Genel Müdürlüğü (2017). Öğretmenlik mesleği genel yeterlilikleri. Ankara: Millî Eğitim Basımevi.

Merriam, S. B. (2013). Nitel araştırma desen ve uygulama için bir rehber (Çev. Ed. S. Turan) Ankara: Nobel Akademik Yayıncılık.

Miles, M. B. \& Huberman, A. M. (1994). Qualitative data analysis: An expanded source book. ( $2^{\text {nd }}$ Edition). California: SAGE Publications.

Muñoz, M. A. \& Prather, J. R. (2011). Exploring teacher effective nessusing hierarchical linear models: Student and classroom-level predictors and cross-year stability in elementary school reading. Planning and Changing, 42(3-4), 241-273.

Nwanekezi, A. U., Okoli, N. J., \& Mezieobi, S. A. (2011). Attitude of student teachers towards teaching practice in the Universityof Port Harcourt, Rivers State, Nigeria. Journal of Emerging Trends in Educational Research and Policy Studies, 2(1), 41-46. 
Oğuz, A. (2004). Okul Deneyimi I dersinin öğretmen adayları üzerindeki etkileri. Dumlupınar Üniversitesi Sosyal Bilimler Dergisi, 11, 141-163.

Ornstein, A. C. ve Hunkins, F. P. (2014). Eğitim programı: Temeller, ilkeler ve sorunlar (Çev. Ed. Asım Arı). Konya: Eğitim Yayınevi.

Özoğlu, M. (2010). Türkiye'de öğretmen yetiştirme sisteminin sorunları. Siyaset, Ekonomi ve Toplum Araştırmaları Vakfi, Seta Analiz, 17(26), 5-35.

Patton, M. Q. (2014). Nitel araştirma yöntemleri, beş yaklaşima göre nitel araştirma ve araştirma deseni. (Çeviri Ed. M. Bütün \& S. B. Demir) Ankara: Siyasal Kitabevi.

Sağdıç, M. (2018). Türkiye'de 2018 yılında uygulamaya konulan sosyal bilgiler öğretmen yetiştirme programinin önceki program ile karşılaştırılması. Uluslararası Sosyal ve Eğitim Bilimleri Dergisi, 5(10) , 308-321. doi: 10.20860/ijoses.488657

Sağlam, M.(2011).Türk eğitim sisteminde ve öğretmen eğitiminde yapısal düzenlemeler ve program geliştirme çalışmaları. S. A. Kilimci (Ed.). Türkiye'de ögretmen yetiştirme içinde (s.137-179). Ankara: Pegem Akademi.

Saylan, N. (2013). Sürekli değişen öğretmen yetiştirme sistemi. Uluslararası Eğitim Programları ve Öğretim Çalışmaları Dergisi, 1(1), 9-17.

Seferoğlu, S. S. (2007). İlköğretim bilgisayar dersi öğretim programı: Eleştirel bir bakış ve uygulamada yaşanan sorunlar. Eurasian Journal of Educational Research (EJER), 29, 99111.

Seferoğlu, S. S. (Kasım, 2009). Yeterlikler, standartlar ve bilişim teknolojilerindeki gelişmeler 1şığında öğretmenlerin sürekli mesleki eğitimi. Eğitimde Yansımalar: IX Türkiye'nin Ögretmen Yetiştirme Çıkmazı Ulusal Sempozyumu (s. 204-217). Başkent Üniversitesi ve Tekışık Eğitim Araştırma Geliştirme Vakfı. Ankara.

Seggie F. N ve Bayburt, Y. (2015). Nitel araştırma, yöntem, teknik, analiz ve yaklaşımları. Ankara: Anı Yayınc1lık.

Silverman, D. (2005). Doing qualitative research: A practical handbook. London: Sage Publication

Şendağ, S. ve Gedik, N. (2015). Yükseköğretim dönüşümünün eşiğinde Türkiye'de öğretmen yetiştirme sorunları: Bir model önerisi, Eğitim Teknolojisi Kuram ve Uygulama, 5 (1),7291.

Şişman, M. (2009). Öğretmen yeterlilikleri: Modern bir söylem ve retorik. İnönü Üniversitesi Ĕ̈itim Fakültesi Dergisi, 10(3), 63-82.

Tangülü, Z., Karadeniz, O. ve Ateş, S. (Mayıs, 2010).Cumhuriyetten günümüze ilköğretime öğretmen yetiştirme. 9.Ulusal Sinıf Öğretmenliği Ĕ̈itimi Sempozyumu (s.1056-1060). Elazı̆g.

Türk Dil Kurumu (2021). Türk Dil Kurumu İnternet Sitesi (http://tdk.gov.tr), Erişim Tarihi: 10.05.2019

Ünsal, S ve Korkmaz F, (2018). Eğitim ve sosyoloji ilişkisi. S. Ünsal ve A. Çetin (Ed.). Eğitim Sosyolojisi içinde (s. 35-58). Ankara: Nobel

Ünsal, S., Çetin, A., Korkmaz, F. ve Aydemir, M. (2019). The change in the curricula: Teachers' perceptions. Çukurova Üniversitesi Eğitim Fakültesi Dergis 48(1), 624-661.

Üstüner, M. (2004). Geçmişten günümüze Türk eğitim sisteminde öğretmen yetiştirme ve günümüz sorunları. İnönü Üniversitesi Eğitim Fakültesi Dergisi, 5(7), 63-78. 
Wright, S.P., Hornand, S.P., \& Sanders, W. L. (1997). Teacher and classroom context effects on student achievement: Implications for teacher evaluation. Journal of Personnel Evaluation in Education, 11, 57-67.

Yaman, E.,Yaman, H. ve Eskicumalı, A. (2001). Öğretmenlik mesleğinin sosyo-ekonomik statüsü. Sakarya Üniversitesi Ĕ̈itim Fakültesi Dergisi, 2, 53-68

Yıldırım, A. (2011). Öğretmen eğitiminde çatışma alanları ve yeniden yapılanma. Uluslararası Ĕgitim Programlarl ve Ögretim Çalışmaları Dergisi, 1(1), 1-17.

Yıldırım, A. ve Şimşek, H. (2011). Sosyal bilimlerde nitel araştırma yöntemleri. Ankara: Seçkin Yayınc1lik

Yirci, R. (2017). Öğretmen profesyonelliğinin önündeki engeller ve çözüm önerileri. Ahi Evran Üniversitesi. Kırşehir Ĕgitim Fakültesi Dergisi, 18(1), 503-522.

Yurdakal, H.İ. (2018). Değişen sınıf öğretmenliği lisans program içeriğinin incelenmesi. Ulakbilge Sosyal Bilimler Dergisi, 6(29), 1483-1499.

Yüksek Öğretim Kurulu. (2007). Öğretmen yetiştirme ve eğitim fakülteleri (1982-2007). Ankara: Meteksan.

Yüksek Öğretim Kurulu. (2018, 2020). Öğretmen yetiştirme lisans programları. www.yok.gov.tr adresinden 10.05.2019 tarihinde erişilmiştir.

\section{EXTENDED ABSTRACT}

\section{Introduction}

Since the transfer of teacher training to universities, various changes have been made in the programs of the faculties depending on the national and international developments and still continue to be made (MoNE, 2017). The ultimate aim of this revision is the "qualification" based trend in teacher training and competencies around the world (Erdem, 2015) and Turkey's efforts to adapt to this trend. The realization of the desired objectives in these regulations depends on the adoption of the program by the practitioners, their willingness to implement the program and their favourable beliefs regarding the fact that the program will work (Ünsal, Çetin, Korkmaz \& Aydemir, 2018; Çetin, 2017). One of the ways of the identification of this situation is to ask the views of the academicians who are the practitioners of the program since the ignorance of the views of the practitioners of the program leads to loss of money, time and energy as well as the failure in the changes (Ornstein and Hunkins, 2014). It is of upmost importance to ask the views of the program practitioners in order to identify the shortcomings in the program and the problems in the implementation along with revealing the perceptions of the practitioners towards the program. Furthermore, the obtained data from the views of the academicians'who are in the position of program practitioners are expected to contribute both to any changes in the current program and to the subsequent program development attempts. Upon analyzing the relevant literature, there is no such a study specified on academicians' views on the change in teacher training programs. This was considered as a gap in the literature by the researchers and such a study was conducted in order to fill this gap. Thus, the problem statement was determined as "What are the views of the academicians' regarding the teacher training program updated in 2018 ?' In this regard, the overall aim of the research is to examine the views of the academicians' about the teacher training program which was renewed in 2018. In service of this aim, answers to the following questions were sought.

Q1. What are the academicians' views regarding the reason for updating the teacher training program? 
Q.2. What are the academicians' views on the changes in the updated teacher training program?

Q.3. What are the academicians' views related to the contribution of the updated teacher training program to the training of qualified teachers?

Q.4.What are the recommendations of the academicians' for the improvement of the teacher training program?

\section{Methods}

This research utilized phenomenological design, one of the qualitative research designs. The studies conducted with phenomenological design are carried out to explicate the perspectives, living experiences and perceptions of the participants towards the phenomenon (Johnson and Christensen, 2012). The phenomenon in the present study is the teacher training undergraduate programs updated in 2018. In phenomenological studies, it should be noted that the participants are the primary individuals who are in the phenomenon and who express the phenomenon (Creswell, 2016; Patton, 2014; Y1ldırım \& Şimşek, 2011). The working group of the research consisted of 10 volunteer academicians (experts) working at the education faculty of a university in Anatolia. The academicians' were coded as E1... E10 in order to comply with the code of ethics. The research data were collected through a semi-structured interview form. Content analysis was used during data analysis. Content analysis involves the identification of codes as a result of in-depth analysis of the data and the formation of themes in line with these codes (Berg and Lune, 2015; Creswell, 2016; Meriam, 2013; Patton, 2014).

\section{Results}

The first question that was sought in this research was to reveal academicians' views on the reasons for the change in teacher training program. The views of the academicians' on the reasons for the change in teacher training program were gathered under the themes such as the problems resulting from the previous program, political reasons and the effort for qualified teacher training. Some of the problems arising from the previous program are the inadequacy in gaining professional skills, uncertainties in the implementation of the program and the abundance of the theoretical courses. One of the reasons for the change in the program is political reasons. The involvement of the educator manager in the HEC board of directors, the efforts to make the program suitable for the Bologna process, and the confusion about how to train teachers were determined as the political factors forcing the program to change. The reasons for the qualified teacher training are; the emergence of the need for teacher training in accordance with the era, the necessity of innovation and diversity of the distribution of courses, the need for change, the need for pedagogically equipped teachers and the change in teachers' competency areas.

The second research question was related to determining the views of the academicians' working at the faculties of education about the changes made in the updated teacher training program. Research findings clarified that academicians' made positive evaluations such as the increase in the type and number of elective courses, the dominance of the implementation, and the clarification of who will teach the courses, giving more importance to the education courses, the integration of moral, ethics and values into the program. On the other hand, they had negative views such as the exclusion of some of the courses and the uncertainty of the content of the courses.

Some of the academicians' views regarding the contribution of the updated teacher training program to teacher training are to provide the training of teachers who will transfer the theory into practice, to ensure the training of teachers with multi-faceted education and to make preservice teachers acquire qualifications.

Another research question was related to the academicians' recommendations for the development of a more qualified teacher training program after 2018. The academicians' 
recommendations for the development of the teacher training program were grouped under three themes: the implementation of the program, the courses, and the selection of students for the program. Academicians' recommendations for the implementation were determined as such; courses and hours regarding implementation should be increased, internship should be started from the lower grades and its duration should be extended, the courses should be taught by the field academicians', scientific studies should be conducted in order to identify the deficiencies in the functioning of the courses and courses should be done in line with the appropriate disciplines. Academicians' recommendations about the courses were identified as; course content should be specified in detail, specific courses should be eliminated from the program, selected elective courses should meet the need. One of the recommendations emphasized by the academicians is about the selection of the students for the program. The academicians' recommended recruiting students by selecting them as teachers. Besides, academicians also suggest that the number of preservice teachers be determined according to the need and that the teachers should be provided the opportunity to study for master degree.

\section{Discussion and Conclusion}

The research results revealed the reasons of the change in teacher training program as problems caused by the previous program, political reasons and the quest for qualified teacher training. Ünsal, Çetin, Korkmaz and Aydemir's (2019) study supports the result of this research regarding the problems and political reasons arising from the previous program. Likewise, the relevant studies emphasized that the problems arising from the previous program (Dinç and Doğan, 2010; Gerek, 2006; Ünsal, et al. 2019), the failure in the programs to respond to the requirements of the era due to the rapid realization and spread of the change (Gülersoy, 2010; Seferoğlu, 2007; Ünsal, et al., 2019) had an effect on the changes in the program. The quest for more qualified and contemporary, multi-faceted, well-equipped teacher training by increasing the quality of qualified teacher training processes is among the reasons for the change in the program. It is likely that the academicians' emphasis on the "quality" in teacher training can be affected by the prominence of the quality in teacher training and competencies (Erdem, 2016) and the discussions made about the quality of teachers in conferences and reports (Yildirım, 2011).

Another result of the research was that the updated teacher training program would contribute to the training of teachers who would transfer the theory into practice. This may be due to the fact that "school experience" course which was previously thought to be ineffective and functional, was removed from the program, and "teaching practice" course was presented in two semesters as teaching practice 1 and 2 with the combination of course content. Teaching profession is a practice profession such as profession of doctor and engineering (Alter and Coggshall, 2009; Grossman and Mc Donald, 2008; Kazu and Yenen, 2015). In this respect, teaching practice course will have great contributions to developing much more effective communication with teacher-student-administration, transferring teaching strategies, methods and learning principles to the classroom and gaining experience about how to cope with disciplinary problems in the classroom (Akbar, 2001; Gujjar, Naoreen, Saifive Bajwa, 2010; Nwanekezi, Okoli and Mezieobi, 2011) along with providing the integrity of theory and practice, adopting the profession as well as understanding the profession better by ensuring concrete experiences to pre-service teachers (Oğuz, 2004). 